\title{
The U.S. Response to Foreign Industrial Targeting
}

There Is GROWING CONCERN in the United States that the economic policies of other countries are hurting the international competitiveness of U.S. industry. This concern goes beyond the usual complaints about foreign competition and trade practices. The magnitude of the harm that foreign economic policies are asserted to be inflicting on the United States and the breadth of support for these assertions are new features of American political discourse. The view that the United States has been massively victimized by the unfair practices of foreign governments has become virtual orthodoxy among many business and labor groups and may well be a central theme of the 1984 presidential election.

U.S. trade policy has traditionally aimed at lowering tariffs and import quotas, and the effort has been largely successful; at least with regard to manufacturing trade among industrial countries, tariffs and formal quotas are now only minor obstacles. The new concern is not focused on these conventional barriers; instead, it addresses the whole spectrum of policies by which a government may promote particular industries. This broad range of policies, called industrial targeting, is the emerging international trade concern of the 1980s.

The policy question raised by this new concern is whether the United States should make a major change in its international bargaining position. For more than a generation the United States has adopted a legalistic approach to trade policy, relying on international agreements and its own legal machinery to defend against "unfair" trade practices

I would like to thank Stephen Russell for research assistance and members of the Brookings Panel for helpful discussions. 
of foreign governments. Many are now saying that this is not enough, that there are policies of foreign governments that hurt the U.S. economy and fall outside the scope of existing trade law. This view calls for a more aggressive U.S. policy, one that pressures foreign governments to abandon certain practices even if these practices would normally be considered domestic in nature. Such a stance necessarily involves threats by the United States to retaliate if its demands are not met; it therefore risks a cycle of retaliation that would restrict world trade and leave everyone worse off.

This paper asks whether the United States should "get tough" with regard to other countries' industrial policies. The answer depends on whether these industrial policies in fact damage the U.S. economy. If they do, it may be worth taking the risks involved in a more aggressive U.S. policy; if they do not, if the rhetoric about foreign targeting is not based on reality, then a tougher U.S. policy is likely to do more harm than good.

Assessing the degree to which foreign industrial policies have hurt the United States is more difficult than most discussions of the issue recognize. Conceptually, the problem can be split into two parts. First, what effect have foreign governments' policies had on U.S. trade? This is a difficult question but not nearly as difficult as the second: what are the consequences of induced shifts in U.S. trade?

The effects of industrial policies on trade cannot be estimated merely by plugging them into a quantitative model and printing out the results. One cannot do this because it is often difficult to establish the facts of foreign countries' policies, and because, even with such information, knowledge of the effects on U.S. trade would be uncertain. It is difficult to establish the facts because explicit industrial targeting rarely, if ever, involves simple initiatives with unambiguous price tags. Instead, targeting encompasses a variety of instruments, including government-sponsored mergers, collaborative research and development, low-interest loans, preferential procurement by government firms, and export credits, whose combined effect is virtually impossible to quantify. The one sure thing is that the officials implementing these policies are almost as uncertain as the researcher about how much support they offer.

But even with good information on the facts of foreign industrial promotion, we would still be uncertain about effects of this promotion on U.S. trade. Quantitative trade models, though they are useful for 
many purposes, are with few exceptions static models of perfectly competitive economics. ${ }^{1}$ But many of the sectors in which targeted industrial policies are alleged to have large effects are both imperfectly competitive and marked by important dynamic features such as steep learning curves and large R\&D expenditures. The theory of trade policy in dynamic and imperfectly competitive industries is still in its infancy; the empirical implementation of the theory has hardly begun.

In view of this situation, I will examine in some detail the actual practices of foreign governments in selected industries. Such an examination can in some cases yield at least a qualitative view of the effect on trade of industrial targeting; in other cases it can at least delineate where the major uncertainties lie. Thus the first section of this paper is a survey of what foreign governments actually do, and an assessment of how those efforts affect U.S. trade.

Even where there is some evidence that foreign industrial policies affect trade, the more difficult task of assessing the consequences for the United States remains. The problem may be illustrated by the case of steel. Suppose that subsidized European steel is being sold in the U.S. market. One view would be that these imports are undercutting U.S. production and employment; the other view would be that the subsidies represent a gift to U.S. consumers. Whether one thinks the United States should retaliate or send a note of thanks depends on how one thinks the U.S. economy works. If one believed that the U.S. economy were characterized by competitive markets in which prices moved quickly to clear those markets, and that there were few serious dynamic costs and benefits, one would not be very worried about foreign targeting. Even if the practices of foreign governments led to a significant distortion of U.S. trade, they could not do much harm to the country as a whole. The only channel through which foreign targeting could hurt the United States would be through a worsening of the U.S. terms of trade, and I will show later that movements in our terms of trade (excluding oil) have not been large enough to be a major source of economic difficulties.

In fact the U.S. economy is not a neoclassical paradise. Not all markets clear quickly, not all industries are perfectly competitive, and

1. An important recent exception is the work of Cox and Harris on the Canadian economy. See David Cox and Richard Harris, "Trade Liberalization and Industrial Organization: Some Estimates for Canada,' Discussion Paper 523 (Queen's University, Institute for Economic Research, 1983). 
dynamic factors are important. But to establish serious injury to the U.S. economy, one must show that foreign practices interact with the imperfections of our domestic economy in such a way as to aggravate them. Such aggravation does not necessarily occur. For example, although subsidized foreign competition might hurt the United States by discouraging some activity that yields valuable external benefits, it might also help by promoting competition in an industry whose firms would otherwise have too much market power. One should not jump from the observation that the U.S. economy is imperfect to the conclusion that the interaction of foreign targeting with our own imperfections is to our detriment. What is needed is not a priori judgment but an examination of cases.

The structure of this paper follows from this observation. The paper describes four seemingly plausible ways in which the industrial policies of foreign governments might be interacting with the imperfections and distortions of the U.S. economy in ways that make the United States worse off. In each case the paper sets forth the channel through which harm might be taking place, then looks for evidence of this harm.

The four imperfections of the U.S. economy that might give rise to harm by foreign targeting are as follows. First is the apparent failure of U.S. labor markets to clear quickly, suggesting that foreign targeting could lead to increased unemployment. Second is the large, unioninduced wage differential that places the income of U.S. steel and auto workers above that in other sectors, which distorts the allocation of labor within the United States in a way that might be aggravated by foreign industrial policies. Third is the reality of imperfect competition in many manufacturing sectors, which opens the possibility that foreign governments could give their firms a strategic advantage in oligopolistic industries. Fourth is the importance of external economies in dynamic, technology-intensive industries, where foreign targeting might be undercutting domestic activities that yield important spillover benefits.

Each of these potential channels for harm from other countries' policies has at least some initial plausibility. However, this paper will show that, as an empirical matter, none of these stories holds up. It would be possible in principle for the industrial policies of foreign governments to do the U.S. economy serious harm, but there is no evidence that they have done so in practice. 


\section{What Foreign Governments Do}

Much discussion of foreign targeting is based on a stylized picture of competition. The picture looks something like this: a foreign government (usually Japan) targets an industry whose firms are initially at a technological and cost disadvantage relative to U.S. firms. Through the government's combination of financial assistance and protection of the domestic market, the industry has time to gain expertise through experience until it is ready to face U.S. firms in the world market. With the advantages both of government support and of a protected domestic base where it can charge high prices to offset the costs of selling abroad at low prices, the foreign industry drives the U.S. firms from the field. U.S. workers are pushed out of high-wage jobs either into unemployment or into low-paying jobs. With their competitors gone, the foreign firms are able to raise prices and realize large profits. And the target industry, carefully chosen to weaken future U.S. competitive ability, serves as a springboard for the next conquest. ${ }^{2}$

In economics, stylized pictures are the first step in any attempt to build a theory, and the account of predatory industrial targeting just described is clear, concise, and powerful in its implications; however, it is a grossly misleading picture of what foreign governments actually do. It is a montage of what has occurred or is alleged to have occurred in various industries, and there is no major industry to which all, or even most, of the story applies.

What do foreign governments actually do? One can distinguish three kinds of policy. The first is financial support, broadly defined to include tax relief, concessional financing, and so on. The second is control of market access, including not only formal tariffs and quotas but also such devices as preferential procurement by governments and governmentcontrolled firms and implicit protection through administrative guidance. The third is rationalization, by which I mean government intervention in market structure or conduct. The most important tools of rationali-

2. A good exposition of this view, by a leading consultant to international business, is William L. Givens, "The U.S. Can No Longer Afford Free Trade," Business Week, November 22, 1982, p. 15. 
zation are government-sponsored mergers designed to create internationally competitive firms, government-encouraged recession cartels to sustain profits in the face of excess capacity, and government-led collaboration in R\&D. The appendix describes how these three types of policy were used in those industries widely believed to have caused the most problems for the United States. The description in the appendix, while not comprehensive, is intended to cover some of the most important sectors in the dispute. It is briefly summarized here.

\section{FINANCIAL SUPPORT}

Financial support should be the easiest form of targeting to quantify. Although a wide variety of financial devices are used by governments, a case-by-case examination gives the strong impression that government financial support is a much smaller factor in industrial targeting than the level of rhetoric suggests. This is particularly true of Japanese industrial policy. ${ }^{3}$ For example, in the area of high-technology competition, massive press coverage has been given to two Japanese programs, the very large scale integration program of the 1970 s and the current fifth generation computer program. Whatever their other aspects, these programs have received only modest financial support from the Japanese government, probably less than $\$ 100$ million per year. Not only are these sums small in absolute terms, they are also of the same order of magnitude as the program in very high speed integrated circuits sponsored by the U.S. Department of Defense. ${ }^{4}$ Foreigners could reasonably allege that in this area of electronics the United States has targeting of comparable magnitude.

3. A skeptical view of the extent of targeting in Japan is given by Gary R. Saxonhouse, “What Is All This About 'Industrial Targeting' in Japan?" in The World Economy, vol. 6 (September 1983), pp. 253-74. Saxonhouse points out (p. 257) that in Japanese manufacturing other than food processing, government subsidies averaged less than 0.1 percent of value added. Subsidies appear to be slightly higher in Europe; though their numbers are not comparable, the European Commission has estimated that central government subsidies amounted in 1978 to 0.4 percent of gross domestic product in West Germany, 0.8 percent in France, and 0.9 percent in the United Kingdom. Much of these subsidies, however, went to services, agriculture, and other sectors not competing with U.S. manufacturing. See Commission of the European Communities, Industrial Policies in the Community: State Intervention and Structural Adjustment (Brussels: CEC, 1981).

4. For a summary of Japanese financial support to the electronics industry in general, see Michael Borrus, James Millstein, and John Zysman, International Competition in 
The aircraft industry is the one major exception to the general proposition that government financial support for industrial targeting is not large. The United States, traditionally dominant in the world market for large commercial aircraft, has now been challenged by Airbus Industrie, a consortium jointly owned by several European governments. Public funds have paid for much of the R\&D for Airbus, and the consortium has received much of its capital at zero interest. Taking present values and annualizing, the government contribution may amount to $\$ 400-\$ 500$ million per year, an amount which is probably a key factor in the U.S. loss of market share. ${ }^{5}$

Aside from aircraft, however, subsidies are not a major factor in industrial country competition in the manufacturing sector. Among developing countries and in agricultural trade they are a far more important factor, but these areas are not relevant for the concern over foreign, especially Japanese, targeting.

\section{MARKET ACCESS}

In contrast to direct financial support, restriction on access to domestic markets either is or has at some time in the past been a significant factor in each of the industries at issue in the targeting debate. In some cases this restriction has taken the form of direct trade barriers such as tariffs and quotas. In other cases, more subtle methods such as preferential procurement by state-owned firms and (allegedly) tacit encouragement of collusion between domestic buyers and suppliers have been used. But what impact have these tactics had on U.S. trade? In particular, to what extent do past protectionist practices by foreign governments still cast a shadow over current trade patterns?

In order to be considered a major factor in international competition, restrictions on market access must do more than provide a privileged position in the domestic market; this privileged position must translate

Advanced Industrial Sectors: Trade and Development in the Semiconductor Industry, prepared for the Joint Economic Committee, 97 Cong. 2 sess. (U.S. Government Printing Office, 1982), especially table 16. William Perry's "Technological Innovation and Industrial Competition," presented to the National Academy of Sciences Panel on Advanced Technology Competition, 1982, estimated the cost of the very high speed integrated circuits program at $\$ 300$ million over five years.

5. An unpublished study by the Office of the U.S. Trade Representative estimated the present value of cumulative support for Airbus from 1968 to 1982 at $\$ 5.7$ billion. 
into an advantage in export markets as well. The conditions under which import restrictions can lead to export advantage are discussed below when I analyze strategic trade policy. To anticipate the conclusions of that discussion, a protected domestic market that serves as a springboard for exports is more characteristic of innovative, high-technology sectors than of mature sectors like autos and steel. The Japanese electronics industry is the most likely example of import protection as export promotion, although even here the case is not watertight.

\section{RATIONALIZATION}

The U.S. approach to antitrust, with its legalistic emphasis on due process, is not duplicated in other countries. In both Europe and Japan, government-sponsored industry reorganizations of various sorts have been used to promote particular sectors. The most important government interventions in market structure have been the support of mergers to create "national champions," sponsorship of recession cartels in difficult times, and sponsorship of collaborative research.

Sponsorship of collaborative research is the only rationalization policy that may have had a major role in influencing U.S. trade. Collaborative research has been the cornerstone of Japan's effort to move its economy toward knowledge-intensive production. The actual effectiveness of these efforts is a matter of considerable dispute, but it is at least possible that joint research has been important in the Japanese success in semiconductors and machine tools.

In sum, although foreign targeting has not had the dominant influence on trade patterns some would suggest, it has probably had important effects on competition in a number of industries. Government financial support has played a major role in aircraft, though not in other industries. Restrictions on access to domestic markets and government-sponsored joint research have probably helped create competition for the United States in high-technology sectors, though probably not in older industries. The result is that foreign targeting has sufficiently affected U.S. trade to make necessary an examination of its consequences for U.S. welfare. I now turn to an examination of channels through which foreign targeting might be harming the United States. 


\section{Foreign Targeting and the Terms of Trade}

Even if the U.S. economy were not characterized by a variety of distortions and imperfections, foreign industrial targeting could reduce U.S. real income through its impact on the terms of trade-the price of exports relative to imports. To the extent that the policies of foreign governments lead to a reduction in the relative price of U.S. exports, they will hurt the U.S. economy.

Although it is not possible to estimate directly any such effects, we can ask what changes in the terms of trade should have been expected in the absence of special targeting. Because of the nature of growth in the rest of the world, it is likely that the U.S. terms of trade would have had a downward trend over the postwar period regardless of the policies of foreign governments, so that the actual decline in the terms of trade provides an upper bound on the effects of foreign targeting. ${ }^{6}$

Broadly speaking, trade theory suggests that growth in the rest of the world will improve U.S. terms of trade if it increases the differences between the United States and the rest of the world and worsen U.S. terms of trade if it reduces the differences. For example, the terms of trade of a capital-abundant country will be improved by additions to the rest of the world's labor force and worsened by additions to the rest of the world's capital stock. During the postwar period the rest of the world has converged toward the capital-labor ratios in the United States, leading to a predicted decline in the U.S. terms of trade.

Table 1 shows shares of resource endowments for 1963 and 1975 for the United States and its major competitors. Two major lessons emerge. First, the U.S. share of world capital and skilled labor has declined, so that a declining U.S. share of world trade is not surprising. The rise of Japan's exports is likewise consistent with its rapid accumulation of capital and skilled labor. Second, the difference between the United

6. Robert Lawrence estimates that if the U.S. and foreign economies were to grow at the trend rates of the 1970s, the relative export price of U.S. manufactures would have to fall by 2 percent per year to maintain balanced trade in manufactures. Robert Z. Lawrence, "Changes in U.S. Industrial Structure: The Role of Global Forces, Secular Trends, and Transitory Cycles," in Federal Reserve Bank of Kansas City, Industrial Change and Public Policy (FRK, 1983), pp. 29-77. 
Table 1. Shares of World Resources, Selected Countries, 1963 and 1975

Percent

\begin{tabular}{lcccc}
\hline $\begin{array}{c}\text { Country } \\
\text { and year }\end{array}$ & Capital & $\begin{array}{c}\text { Skilled } \\
\text { labor }\end{array}$ & $\begin{array}{c}\text { Semi- } \\
\text { skilled } \\
\text { labor }\end{array}$ & $\begin{array}{c}\text { Arable } \\
\text { land }\end{array}$ \\
\hline $\begin{array}{l}\text { United States } \\
1963\end{array}$ & 41.93 & 29.36 & 18.27 & 27.44 \\
1975 & 33.43 & 26.33 & 19.09 & 29.25 \\
Japan & & & & \\
1963 & 7.09 & 7.84 & 12.56 & 0.90 \\
1975 & 14.74 & 8.62 & 12.33 & 0.78 \\
West Germany & & & & \\
1963 & 9.12 & 7.08 & 6.79 & 1.29 \\
1975 & 8.27 & 6.56 & 5.79 & 1.13 \\
France & & & & \\
1963 & 7.14 & 6.57 & 5.25 & 3.18 \\
1975 & 7.94 & 6.24 & 4.49 & 2.63 \\
United Kingdom & & & & \\
1963 & 5.60 & 6.97 & 6.48 & 1.13 \\
1975 & 4.89 & 6.44 & 5.32 & 0.98 \\
\hline
\end{tabular}

Source: Harry P. Bowen, "Changes in the International Distribution of Resources and Their Impact on U.S. Comparative Advantage," Review of Economics and Statistics, vol. 65 (August 1983), p. 405.

States and the rest of the world has clearly been narrowing. The U.S. share of resource endowments declined in two of the three factors in which we were relatively most abundant in 1963, capital and skilled labor. The world was becoming more like the United States.

Less tangible than the role of the factors shown in table 1 but pointing in the same direction is the role of technology in trade. The United States has been an exporter of technologically sophisticated products; a decline in U.S. terms of trade is expected as the rest of the world gains in technological sophistication.

These tendencies mean that the real-income effect of the declining U.S. terms of trade is a maximum estimate of the effects of foreign targeting through this channel. The real income effects of declining terms of trade have been small, and thus the effects of targeting must have been smaller. In 1980 exports of manufactures amounted to about 6 percent of U.S. GNP. A decline of 2 percent per year in the relative price of these goods would reduce U.S. real income growth by roughly 0.12 percent per year. Although significant, this is a small amount, far from being the size envisioned by those who see a loss of competitiveness as 
a key U.S. economic problem. Furthermore, as noted, it is unlikely that all or even most of the decline can be attributed to foreign industrial policies. Last, since 1980, the sharp real appreciation of the dollar has substantially improved the U.S. terms of trade.

The inevitable conclusion is that any serious adverse impacts from foreign industrial targeting must be occurring through channels other than the terms of trade. That is, targeting must be aggravating existing distortions and imperfections in the U.S. economy. The remainder of this paper will examine a series of possible interactions between domestic market failures and foreign industrial policies.

\section{Foreign Targeting and Unemployment}

Most of those concerned over foreign targeting argue that unfair foreign competition has taken away U.S. jobs. Economics offers more than one reason to believe that microeconomic policies will not have significant effects on aggregate employment. The economy has an automatic tendency, after a disturbance, to return to some natural level of unemployment, although there is substantial disagreement about the length of time this takes. More important, even economists who believe that labor markets take a long time to clear view aggregate employment as largely a macroeconomic problem, amenable to macroeconomic policy instruments. Finally, foreign competition, whether fair or unfair, need not affect aggregate U.S. employment because its effects can be offset by movements in the real exchange rate.

A different employment argument holds that, although the economy can adjust employment among sectors so as to avoid aggregate employment effects from trade, foreign competition has steadily eroded the U.S. industrial base. As a result, the United States has done badly compared with other countries at sustaining manufacturing output and employment. It is something of a shock, therefore, to look at the actual numbers. They support neither the idea that the United States has suffered a loss of industrial employment due to a loss of competitiveness nor the idea that manufacturing has been doing worse in the United States than in other industrial countries.

Table 2 presents three indicators of the aggregate competitive performance of U.S. manufacturing during the 1970 s and early $1980 \mathrm{~s}$. The 
Table 2. Indicators of U.S. Competitiveness in Manufacturing, 1973-82 Percent

\begin{tabular}{|c|c|c|c|}
\hline Year & $\begin{array}{l}\text { U.S. manufac- } \\
\text { turing trade bal- } \\
\text { ance as percent } \\
\text { of manufactur- } \\
\text { ing output }\end{array}$ & $\begin{array}{c}\text { U.S. share } \\
\text { in OECD } \\
\text { manufacturing } \\
\text { output }\end{array}$ & $\begin{array}{l}\text { U.S. share in } \\
\text { OECD industrial } \\
\text { employment }\end{array}$ \\
\hline 1973 & -0.1 & 36 & 25.6 \\
\hline 1974 & 2.4 & 36 & 25.5 \\
\hline 1975 & 5.6 & 35 & 24.8 \\
\hline 1976 & 3.0 & 36 & 25.7 \\
\hline 1977 & 0.8 & 37 & 26.4 \\
\hline 1978 & -1.1 & 37 & 27.5 \\
\hline 1979 & 0.8 & 37 & 28.2 \\
\hline 1980 & 3.2 & 36 & 27.7 \\
\hline 1981 & 3.0 & 37 & 28.0 \\
\hline 1982 & -1.2 & 36 & n.a. \\
\hline
\end{tabular}

Source: For first column, Economic Report of the President, February 1983; for second column, Organization for Economic Cooperation and Development, Indicators of Industrial Activity (Paris: OECD), various issues; for third column, OECD, Labour Force Statistics, 1970-1981, pp. 30-31.

n.a. Not available.

first indicator is the U.S. trade balance in manufacturing as a percent of manufacturing output. Over the measured period it has remained a small number, usually positive, with no discernible trend, suggesting that changes in trade flows have had little effect on manufacturing employment. This implication would not hold if there were a strong bias toward increased net imports of labor-intensive goods, but another recent study by Lawrence, which examines the employment effects of trade using the input-output table, finds that this is not the case; changes in trade from 1970 to 1980 had a slight, positive effect on U.S. manufacturing employment. ${ }^{7}$

The other indicators in table 2 show two measures of relative U.S. performance in manufacturing: the U.S. share of total manufacturing output in the countries of the Organization for Economic Cooperation and Development (OECD) and the U.S. share of OECD industrial employment. These numbers do not directly measure the impact of trade on U.S. employment, but they show that the disappointing performance of U.S. manufacturing has been part of a worldwide slowdown rather than the counterpart of rapid industrial growth abroad.

Although the United States did not experience deindustrialization

7. Robert Z. Lawrence, "Is Trade Deindustrializing America? A Medium-Term Perspective," BPEA, 1:1983, pp. 129-69. 
through trade in the 1970s, would it have had a sharply growing trade surplus in manufactured goods if it had not been for foreign targeting? On the one hand, the OECD as a whole had a growing trade surplus in manufactures during the 1970 s, offsetting increasing oil bills. On the other hand, long-run trends in saving and investment were probably pushing the United States toward reduced current account surpluses. On balance there is nothing in the U.S. experience during the 1970s that reveals major effects from the trade and industrial policies of foreign countries.

\section{Foreign Targeting as a Source of Wage Loss}

Although there is no evidence that targeting has added significantly to U.S. unemployment, some would argue that workers displaced by foreign targeting are reemployed in less productive and lower-paying jobs-twenty-three-dollar-an-hour steelworkers displaced into five-dollar-an-hour jobs flipping hamburgers.

There is no question that workers displaced from jobs by foreign competition, like workers displaced by any economic change, often suffer substantial losses of income. In the day-to-day practice of trade policy the discussion often stops at this point. In itself, however, the displacement of some U.S. workers into lower-paying jobs is not a sufficient reason to adopt a tougher trade policy. We need to ask who, if anyone, benefits at the expense of displaced workers. Are the beneficiaries domestic consumers, so that wage losses to some represent changes in domestic income distribution? Or is the loss of wages a loss of overall national income?

\section{INTERPRETING WAGE LOSSES FROM FOREIGN COMPETITION}

From the late 1950s to the early 1970s the analysis of international competition, wages, and national income was a centerpiece of trade theory for developing countries. ${ }^{8}$ The discussion clearly sorted out the arguments and can be translated directly to the U.S. context.

8. For a survey of these arguments, see Harry G. Johnson, "Optimal Trade Intervention in the Presence of Domestic Distortions," in Richard E. Caves, Harry G. Johnson, and Peter B. Kenen, eds., Trade, Growth, and the Balance of Payments: Essays in Honor of Gottfried Haberler (Amsterdam: North-Holland, 1965), pp. 3-34. 
Consider a U.S. industry that, under the pressure of increased import competition, suffers a drop in wages and employment and sees its displaced workers end up in lower-paying jobs. Does this represent a net loss of income to the economy or does it simply represent a redistribution of income from its workers to its consumers?

If foreign competition forces a fall in the price of their industry's product, workers' wages in the industry might fall for one or more of the following reasons: first, because they were unable or unwilling to move to other jobs; second, because their initial earnings partly reflected training or experience specific to the industry; and third, because their wages had been higher than what they could have earned elsewhere for institutional reasons such as unionization.

If the workers are unwilling or unable to move, they may be forced to accept lower wages to retain their jobs. If the United States is not a net exporter of the product, their loss is at least matched by the gain to consumers. If the United States is a net exporter of the product, any loss shows up in the terms of trade, and we have already seen that the effects of foreign targeting on U.S. national income via the terms of trade are minor at most.

If workers are free to move but lose because their previous earnings reflected industry-specific skills, the same argument applies. The losses of the affected workers are a mirror image of gains by consumers. The main difference from the case of immobile workers is that the workers will be worse off even if they move to other industries because the value of their skills has been reduced. But this does not reflect a decline in their productivity; it reflects a capital loss on their skills, the same as the losses experienced by investors when economic change makes their assets less valuable. A parallel would be a decline in the value of land in a net food-importing country when the price of imports declines: the land has not become less productive, and the loss to landowners is more than matched by the gain to consumers.

Only in the last case, in which workers displaced from an industry suffer losses because wages in that industry were initially raised above the opportunity cost of labor by some institutional factor, could the displacement represent a net loss, and then only if the foreign competition does not improve consumers' welfare by more than the loss experienced by the industry's workers. This possibility arises because the allocation of labor was distorted to begin with: too little labor was employed in the industry, and foreign competition drove down employment even further. 
Figure 1. High-Wage Sectors and Foreign Competition

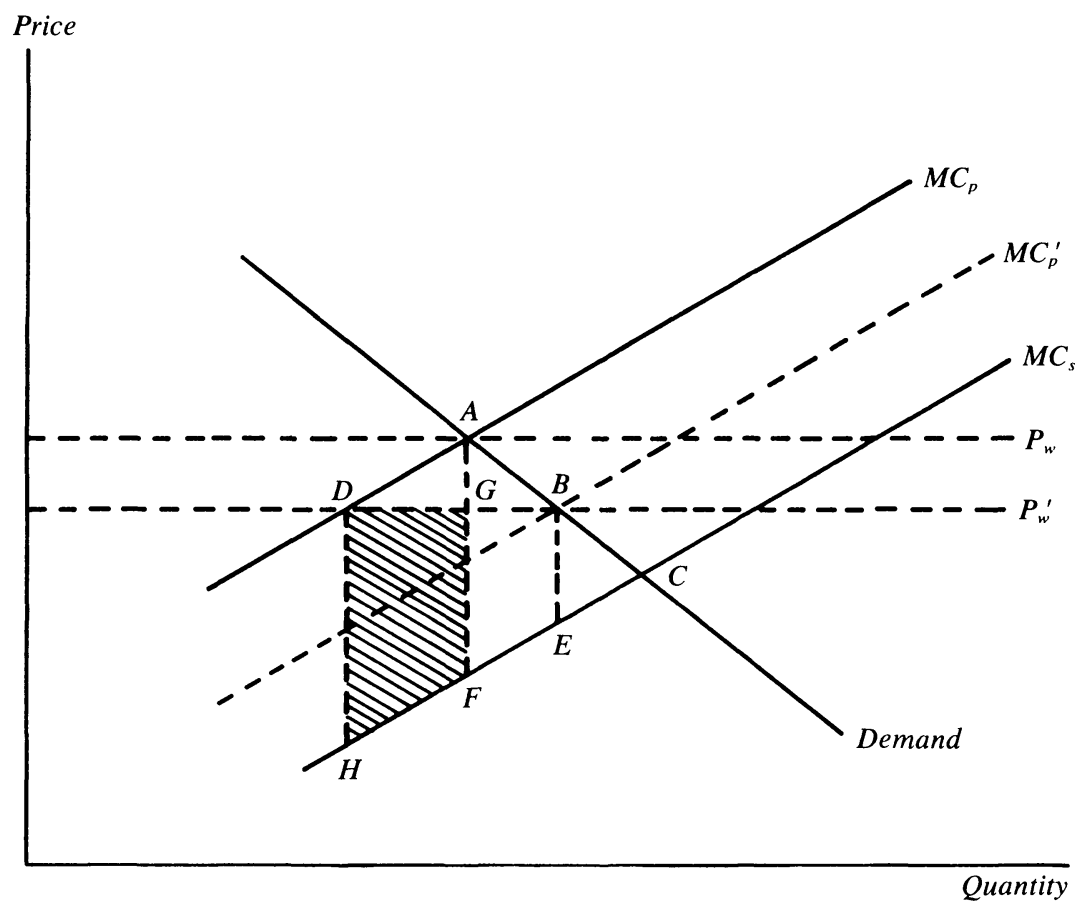

This fits with our general principle that foreign targeting is likely to cause serious losses only if it exacerbates preexisting distortions in our own economy. In this case the initial distortion is the misallocation of resources resulting from an artificial wage differential.

The nature of the potential loss from foreign competition when relative wages are distorted is illustrated by figure $1 .{ }^{9}$ The figure shows an industry that initially sells its output at a world price $P_{w}$, then is confronted with foreign targeting that drives the world price down to $P_{w}^{\prime}$. To remove terms-of-trade effects, the figure is drawn under the assumption that there is initially no net trade in the industry. If the country were initially an importer, a fall in $\boldsymbol{P}_{\boldsymbol{w}}$ would produce a terms-of-trade gain; if it were initially an exporter, it would produce a terms-of-trade loss.

The domestic industry's supply is determined by setting price equal to private marginal cost $M C_{p}$, which is determined by industry wages

9. This diagram was suggested by Robert Lawrence. 
that include an artificial premium. The social marginal cost curve $M C_{s}$, which reflects the opportunity cost of labor rather than its wage, lies below $M C_{p}$. The marginal cost curves are shown with an upward slope, although in the long run they might become horizontal as capacity is allowed to expand. With the introduction of foreign competition that drives down the price to $\boldsymbol{P}_{w}^{\prime}$, domestic production moves from A to D and consumption moves from $\mathrm{A}$ to $\mathrm{B}$ if the gap between $M C_{p}$ and $M C_{s}$ is assumed to be unaffected, that is, if foreign competition does not affect the industry's wage premium. In this case, foreign competition leads to a reduction in domestic output, which was already too low because the social marginal cost was less than the price. The consumption gain is measured by $\mathrm{ABEF}$, as the distortion of price exceeding $M C_{s}$ shrinks from $\mathrm{ACF}$ to $\mathrm{BCE}$. But $\mathrm{DBEH}$ of producers' surplus is now going to foreigners rather than to the domestic industry. The net of these two effects is the difference between ABG and the shaded area, DGFH.

If $\mathrm{ABG}$ is relatively small, either because demand is inelastic or because the price decline is small, there will be a net loss of real income to the nation approximated by the shaded area. This loss exists because of the difference between the wages paid to workers in the targeted sector and their opportunity wages elsewhere, and because part of the difference between price and marginal social cost to which this wage differential gives rise now accrues to foreigners. Its size is approximated by the wage differential times the lost employment, or the loss in wage bill in the targeted industry.

If foreign competition pushes down the wage premium in the targeted sector, so that $M C_{p}$ moves toward $M C_{s}$, this effect will be modified and there is a greater likelihood that foreign competition will produce a real income gain to the nation. To take a simple case, if incipient foreign competition reduced the wage premium so as to shift $M C_{p}$ to $M C_{p}^{\prime}$ as the price fell from $P_{w}$ to $P_{w}^{\prime}$, employment in the industry would expand to produce the higher output at the lower price. The real national income loss that existed because of the initial wage premium in the industry would shrink from the triangle ACF to the triangle $\mathrm{BCE}$.

\section{FOREIGN COMPETITION AND HIGH-WAGE SECTORS}

If foreign competition has little effect on the wage differential itself, and if demand is inelastic so that consumption does not expand much, 
then the displacement of high-wage jobs by imports generates a real national income loss which, as noted, can be approximated by the job loss multiplied by the wage differential. Thus ideally we could assess such losses by calculating institutional wage differentials for each industry and calculating the number of workers displaced by foreign targeting in those sectors with a positive differential. Needless to say, this project is not possible. The best we can hope to do is to identify likely candidates for underemployment generated by foreign targeting. To do this, I first look for sectors that have had both an unfavorable trade performance and unusually high wages. I then ask to what extent their wages reflected institutional factors and how much of their adverse performance can be explained by the policies of foreign governments.

There are some problems with this approach. We may be missing cases where trade performance was favorable but would have been even more favorable if foreign governments had not intervened (aircraft?). And we may also be missing industries that pay wages which are low in absolute terms but high given the low skills of their workers (apparel?). Nonetheless, our procedure will give at least a tentative view of the extent to which foreign targeting is driving the United States out of high value-added sectors.

Figure 2 shows a preliminary attempt to identify industries in which foreign competition has displaced U.S. workers from high-paying jobs. On the horizontal axis is the wage rate of production workers. On the vertical axis is one measure of trade performance: the change in the ratio of net exports to total (domestic plus export) shipments from 1973 to 1981. Industries in the lower right of the figure have both high wages and a poor competitive record. The results shown in figure 2 are striking. The impressionistic view of autos as a high-wage industry that has suffered from foreign competition is correct. But it is not an example of something going on in a variety of sectors. Instead, the motor vehicle industry appears to be unique.

Readers may be surprised that the steel industry does not appear in this category. As the appendix documents, the U.S. steel industry was effectively protected by a mixture of formal and tacit measures that kept the import share from rising during the period on which the figure is based. Over a longer horizon, reaching back to 1960 , or presumably in the absence of protection currently, steel would join autos in the highwage, poor-trade-performance category. 


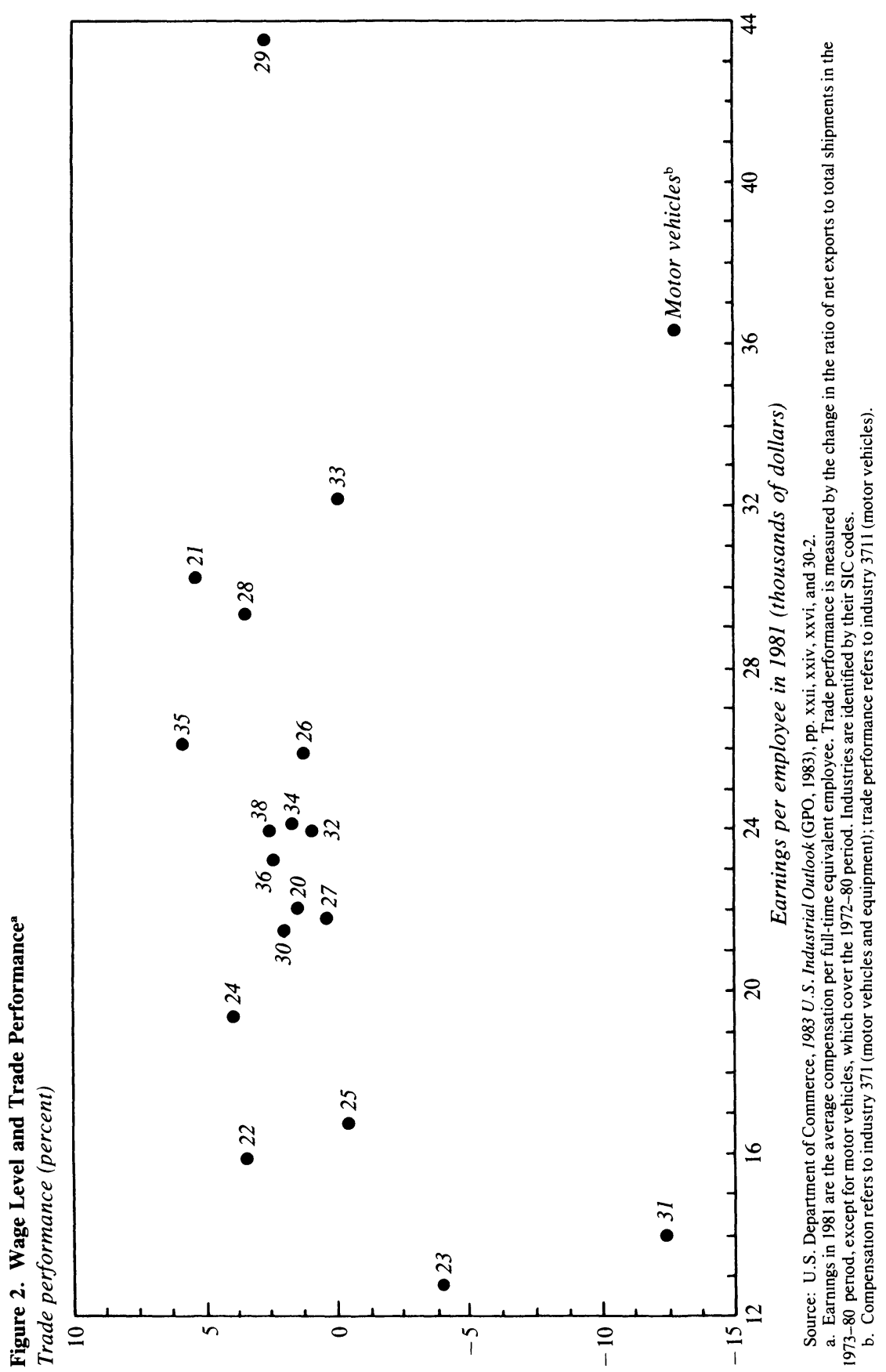


The results in figure 2 mean we need analyze only two distinctive and well-documented industries. The analysis must answer two questions. First, to what extent do high wages in autos and steel reflect institutional factors rather than high skills? Second, to what extent does the poor competitive performance of these sectors reflect the industrial policies of other countries?

The answer to the first question is straightforward. The wages of auto and steel workers are high mainly because of the strength of their unions rather than the human capital of their workers. The labor forces are not highly skilled by usual measures, yet their compensation is far above average, with differentials that are substantially larger than those in other countries, and also substantially increased from their levels in the 1960s.

In regard to the second question, the trade problems of the auto industry are essentially a matter of Japanese competition. The Japanese auto industry received infant-industry protection before the early $1960 \mathrm{~s}$ but by all accounts has received little government support since then. ${ }^{10}$ The trade problems of the U.S. auto industry, by contrast, became severe only after 1979. Mostly because of low U.S. gasoline prices, the characteristics of U.S. auto demand had been sufficiently different from those elsewhere to effectively limit foreign competition to a marginal piece of the U.S. market. Only with the 1979 oil price increase and subsequent deregulation of domestic prices did the main U.S. market become susceptible to foreign competition. ${ }^{11}$ Unless one is willing to attribute the post-1979 auto import surge to Japanese policies that disappeared almost two decades earlier, the poor trade performance of the auto industry cannot be blamed on foreign targeting.

Steel is a more disputed case. Japan did provide special support to its steel industry, but the importance of the targeting is questionable; European aid to steel has been substantial, but its importance to U.S. trade is doubtful. Because the U.S. steel industry has for practical purposes had a quota on imports since the early 1970 s, the sum of foreign and U.S. policies has presumably sustained rather than reduced steel industry employment.

10. See U.S. International Trade Commission, Foreign Industrial Targeting and Its Effects on U.S. Industries, Phase I: Japan (Washington, D.C.: ITC, 1983), pp. 129-31.

11. See U.S. Department of Commerce, The U.S. Automobile Industry, 1982 (U.S. Department of Commerce, 1983), pp.9-15. 
In sum, then, foreign competition in autos and steel has actually-or, without protection, potentially-displaced U.S. workers from high-wage jobs, and in these cases at least some of the wage loss represents a net cost to the U.S. economy rather than simply a redistribution from one set of U.S. residents to another. This downgrading of workers, however, is essentially limited to the auto and steel industries and is not typical of the economy as a whole; and there is no good case for arguing that foreign targeting has been important in the loss of competitiveness of autos or has been a major factor in steel.

However, the wage loss exists even if the practices of foreign governments are not responsible for it. Should it cause us to protect autos and steel regardless of the role of foreigners?

\section{WAGE DIFFERENTIALS AS A CASE FOR PROTECTION}

The best way to deal with institutional wage differentials is to eliminate them or, failing that, to offset their distorting effects on output by subsidizing employment in the high-wage sectors. Neither of these seems practical in a U.S. context. It is hard to imagine, for instance, the U.S. political system supporting a general subsidy to the wages of auto and steel workers or a plan to destroy their unions.

If the best policy is not available, there is a second-best case for using trade policy. The discussion has suggested a point which may easily be confirmed by formal modeling: if we take the wage differential as given, a sufficiently small protective tariff on a high-wage sector will raise national income by inducing more labor to move into that sector. ${ }^{12}$

It is wrong to assume that wages in unionized industries are independent of the protection they receive. Protecting a high-wage sector may end up sustaining the wage differential rather than offsetting that differential's distorting effect on resource allocation. Since a policy of protecting workers who already earn well above the average is (or would be if the public understood it) hard to justify in distributional terms, it is hard to use wage differentials as an argument for protecting autos and steel.

Although the unresolved theoretical and empirical issues regarding wages and foreign competition are numerous, the policy conclusion

12. See Jagdish Bhagwati and V. K. Ramaswami, "Domestic Distortions, Tariffs and the Theory of Optimum Subsidy,' Journal of Political Economy, vol. 71 (February 1963), pp. 44-50. 
seems clear: high-wage industries in the United States have suffered from foreign competition, but the competition has not been the result of government targeting. At the same time, the case for protecting highwage industries in the absence of any unfair practices by foreign governments is weak. Thus employment losses in high-wage industries are not a good reason for the United States to adopt a more aggressive trade policy.

\section{Foreign Targeting and Profit Losses}

A common complaint of business executives is that they do not face their foreign rivals on a "level playing field." To the extent that this assertion reflects the belief that foreign governments subsidize and protect everything, it ignores the indirect and general equilibrium effects that make such universal promotion impossible. Complaints about a "level playing field" can be given another, more sophisticated, interpretation: that adroit government policies can alter the rules of the game in international oligopolistic competition so that their firms capture more than their share of excess returns. Instead of picking winners, it is argued, these policies make winners. Recent theoretical work has indeed suggested the possibility of carefully targeted government policies that play the strategic role of shifting the terms of subsequent competition; this work appears to justify activist policies on the part of our own government and protection against the policies of other governments.

Sophisticated critics of the case for free trade have always argued that the theory does not hold in the absence of perfectly competitive markets. Recently, theorists have begun modeling the effects of trade and industrial policy under imperfect competition, and the results have at least partly justified the critics of free trade. Imperfect competition does furnish new arguments for intervention in international trade. These arguments, however, offer only a limited guide to policy.

THE THEORY OF STRATEGIC INDUSTRIAL POLICY

The theory of strategic industrial policy was proposed in recent, seminal papers by Brander and Spencer. ${ }^{13}$ Their theory is that govern-

13. James A. Brander and Barbara J. Spencer, "Tariff Protection and Imperfect Competition," in Henryk Kierzkowski, ed., Monopolistic Competition and International 
ment action can increase national income through its deterrent effect on foreign firms. Subsidies or protection for domestic firms, says the theory, can deter foreign competitors from investing as much in R\&D, capacity, and learning as they would have otherwise, raising the returns earned by the home firms. The key is that government intervention affects the actions of foreign firms rather than those of domestic ones. As a result, a subsidy increases domestic profits more than the amount of the subsidy and a policy of protection benefits domestic producers more than it hurts consumers.

The following simple numerical example can demonstrate the possibilities of strategic trade policy as well as its problems. Consider two countries, both of which have the same potential demand for a new product, say digital widgets. The demand for digital widgets in each country is linear:

$$
\begin{aligned}
q & =6-p \\
q^{*} & =6-p^{*},
\end{aligned}
$$

where prices, $p$, are measured in dollars per widget, quantities, $q$, are measured in millions, and asterisks denote variables for the second country. In the absence of trade restrictions, $p=p^{*}$, and world demand is then

$$
q+q^{*}=12-2 p .
$$

There are two firms, one in each country. Either firm or both can develop a digital widget. To do so and to equip the factory costs $\$ 7$ million. Once the investment is made, however, the advanced production technology allows production at zero cost. After the firms have decided whether or not to invest, they will be in a conventional duopoly situation. I will assume that the firms behave in Cournot fashion: each chooses its profit-maximizing output, taking the other firm's output as given. In equilibrium, if only one firm develops digital widgets, it will charge a price of $\$ 3$ and sell 3 million units; if both firms enter, they will charge $\$ 2$ and each will sell 4 million units.

To analyze the entry decision, look at the matrix of possible outcomes. For the decisions of firms, the crucial point is the profit level in each

Trade (Oxford University Press, forthcoming). Also Barbara J. Spencer and James A. Brander, "International R\&D Rivalry and Industrial Strategy," Review of Economic Studies, forthcoming. 
Table 3. Model of Cournot Duopoly Competitiona

\begin{tabular}{|c|c|c|c|c|}
\hline \multirow{3}{*}{$\begin{array}{c}\text { Home-firm } \\
\text { options }\end{array}$} & \multicolumn{4}{|c|}{ Foreign-firm options } \\
\hline & \multicolumn{2}{|c|}{ Free trade } & \multicolumn{2}{|c|}{ Protected home market } \\
\hline & Enter & Don't enter & Enter & Don't enter \\
\hline Enter & $(8,1,1)$ & $(4.5,11,0)$ & $(4.5,6,-3)$ & $(4.5,11,0)$ \\
\hline Don't enter & $(4.5,0,11)$ & $(0,0,0)$ & $(0,0,1)$ & $(0,0,0)$ \\
\hline
\end{tabular}

a. In each entry the first number is the value of the consumer surplus in the home country, the second is the profit of the home country's firm, and the third is the profit of the foreign country's firm.

outcome; to consider the additional question of policy, however, it will be useful to examine the consumer surplus in the home country in each situation. Table 3 shows the profits and consumer surplus for each combination of decisions by firms. The first number is the value of consumer surplus in the home country, the second is the profits of the home country's firm, and the third is the profits of the foreign country's firm.

Given the parameters of this example, both firms will find it profitable to enter, and the free trade equilibrium will be one in which there is a duopoly. The price in the world market will be $\$ 2$, and the sum of consumer and producer surpluses in the home country (the first two numbers) is $\$ 9$ million.

It is apparent from table 3 that, if it could, the home country's government would want to deter the foreign firm from entering the market; the outcome would be moved to the upper right hand free-trade entry, in which the decline in the consumer surplus would be more than offset by a gain in profits. The sum of consumer and producer surpluses would rise from $\$ 9$ million to $\$ 15.5$ million.

How can the domestic government deter the foreign firm from entering? One way is to ban imports of digital widgets. The simplest way to see this is to suppose that the protected firm is able to discriminate between markets, acting as a monopolist in the domestic market while competing as a duopolist in the foreign market. In the domestic market it will have sales of 3 million units at $\$ 3$ per unit; in the foreign market each firm will sell 2 million units at $\$ 2$ per unit if both firms enter. But the resulting payoff matrix (the protected-home-market entries in table 3) shows that the foreign firm will choose not to enter, abandoning the field and the profits to the domestic firm.

Although this is a hugely oversimplified and contrived example, it 
illustrates two important points which give at least some justification for concern about foreign industrial targeting. First, it shows an unfamiliar channel through which protection could benefit a country at the expense of its trading partners. This channel is quite different from the usual, optimum-tariff approach. Second, it illustrates the possible importance of limitations on market access as a competitive strategy. Note that in the example a restriction on imports allows the domestic firm to dominate the foreign market as well as the domestic market. Import protection turns out to be export promotion. Since the possibility that a protected domestic market can serve as a springboard for exports is crucial to much discussion of trade policy, this point needs to be enlarged upon.

The traditional "infant industry" argument says that protection of the home market can eventually make the home industry internationally competitive. As usually stated, this argument depends on the existence of external dynamic economies of the sort discussed in the next section of this paper: there is an industry-wide learning curve in which firms gain from the experience of other firms. In this case, a temporary period of protection might give an industry a chance to move down the curve and become internationally competitive. The key to this argument is that firms are not able to fully internalize the benefits of the knowledge they generate through production experience. Furthermore, the process through which a protected market promotes exports must be sequential: at first the domestic industry is a high-cost producer requiring protection, but later it becomes a low-cost producer and protection is redundant.

The role of a protected domestic market suggested by our example is quite different. As in the traditional infant industry case, dynamic economies of scale are crucial, but here they are internal rather than external economies. In the example these economies take the form of front-end $R \& D$ costs, but similar examples can be constructed where the dynamic economies take the form of a learning curve internal to the firm. ${ }^{14}$ Also, the sequence in which initial protection is followed by later competitiveness is no longer present: the expectation of protection, by affecting firms' strategic decisions, leads to immediate exporting by the

14. For a formal analysis of competition in the presence of a learning curve, see A. Michael Spence, "The Learning Curve and Competition," Bell Journal of Economics, vol. 12 (Spring 1981), pp. 49-70. An application to international competition is Paul Krugman, "Import Protection as Export Promotion: International Competition in the Presence of Oligopoly and Economies of Scale," in Kierzkowski, ed., Monopolistic Competition. 
"protected" firm. The expectation of protection does all the work. In the actual equilibrium the protection does not take place because the foreign firm does not actually enter. This means that conventional indicators of government intervention in trade such as average rates of protection could be misleading. A cleverly contrived government policy could in principle deter foreign competition in key sectors by threatening to close market access while having to enact relatively little actual protection by conventional measures.

The theory of strategic trade policy, then, appears to open the door for considerable worry about the effects of foreign industrial targeting. It suggests that a country can "rig the game" in oligopolistic competition so as to allow its firms excess returns at the expense of their competitors; and it suggests that such policies need not involve large actual subsidies or high current protective barriers.

There is an obvious danger that this new set of ideas will simply be invoked to defend any and all accusations against foreign countries. To keep the implications in perspective, it is necessary to do two things. First, we must take into account the problems and weaknesses of the theory in general. Second, we must ask whether the view of predatory industrial policy suggested by the example represents what actually happens.

\section{CRITICISMS OF THE THEORY}

Although it is a new concept, the theory of strategic trade policy has already drawn considerable fire. ${ }^{15}$ There are five main criticisms, ranging from narrow technical issues to questions about the underlying structure of the game being played. (1) The argument for strategic industrial policies is highly sensitive to parameters about which we have very imperfect knowledge. (2) The argument is also highly sensitive to assumptions about the competitive strategies of firms, and the most common assumptions are unsatisfactory. (3) The theory assumes a structure in which governments are able to make commitments but firms are not, which may be unrealistic. (4) Activist policy of the type suggested by the theory would provoke retaliation by foreign governments and thus be counterproductive. (5) Given the political economy of trade

15. See in particular Avinash Dixit, "International Trade Policy for Oligopolistic Industries, ' Economic Journal, supplement, vol. 94 (1983), pp. 1-16. 
policy, strategic considerations of this type would merely open the door to pure and simple protectionism. Each of these criticisms can be summarized briefly.

Sensitivity to Parameters. The case for any particular industrial policy and the case for domestic injury from any given foreign industrial policy hinge crucially on the numbers: the cost of $R \& D$, the slope of the learning curve, the number of potential competitors, the size and rate of growth of the market, and so on. Laissez faire may not be the optimal policy, but the optimal policy may be hard to determine, even in qualitative terms. For example, a recent paper by Dixit and Grossman ${ }^{16}$ shows that even in a highly simplified model of strategic policy, the case for promoting any one sector becomes very uncertain once general equilibrium complications are taken into account. By promoting a particular sector, the government crowds out others; and one needs to ascertain whether the excess returns gained in the favored sector are greater than those lost elsewhere. Few of the studies that advocate an activist U.S. industrial policy or allege injury from foreign policies make any effort to provide the kind of information needed.

Sensitivity to Assumptions about Behavior. This weakness is special to the theory of strategic industrial policy and creates an extra reason for caution. The original Brander-Spencer analysis showed that export subsidies were a desirable policy in a duopoly model of international competition. Recent analysis by Eaton and Grossman ${ }^{17}$ shows that this result is crucially dependent on the assumption of Cournot behavior by firms. With other behavior, not only could the optimal policy be driven back to be one of free trade, it could actually reverse to become one of taxing exports.

The Relationship between Governments and Firms. The usual assumption in models of strategic industrial policy is that the activist

16. Avinash K. Dixit and Gene M. Grossman, "Targeted Export Promotion with Several Oligopolistic Industries," Discussion Paper 71 (Princeton University, Woodrow Wilson School, 1984).

17. Jonathan Eaton and Gene M. Grossman, "Optimal Trade and Industrial Policy under Oligopoly,"' Discussion Paper 59 (Princeton University, Woodrow Wilson School, 1983). Although Eaton and Grossman's argument appears quite devastating to the case for export subsidies, it is much less serious when applied to other policies. In particular, subsidies to either investment or R\&D, which affect long-run competitive moves, are likely to work in a Brander-Spencer fashion whatever the character of short-run competition. 
country's government moves first, announcing a policy that determines the outcome of the subsequent game. Firms do not themselves make strategic moves aimed at government. This is not a fully satisfactory view of the situation. The type of industry to which the theory is intended to apply is one where there are a small number of competitors, and governments are making detailed interventions rather than broad, economy-wide policies. In this kind of industry firms can and do attempt to make precommitments that affect government behavior as well as the behavior of other firms. This can seriously weaken the ability of governments to carry out the kind of clever policy illustrated by the example of digital widgets.

This point may be illustrated by a real case. The principal competitors in the large commercial aircraft industry are Boeing and the Europeangovernment-supported Airbus Industrie. The newest area of potential competition is in 150-seat aircraft. The theory of strategic competition might lead us to expect that European governments, to deter Boeing from entering, would make a highly public commitment to the market. In fact, the reverse is happening: Boeing has announced its plans first and is publicizing the view that there is no room for a second entry, that is, that the subsidy costs will be too high for the Airbus sponsors. Whether this strategy will work is uncertain, but in any event the government is not in the position assumed by the Brander-Spencer model, that of first mover. ${ }^{18}$

Retaliation. Strategic industrial policy is essentially a beggar-myneighbor policy and would be a risky enterprise given the threat of retaliation. Too easy an acceptance of the theory could lead to a mutually harmful trade war, fragmenting markets and reducing competition.

Domestic Politics. The most important strategic game being played in international economic policy may be neither the competition between firms nor the rivalry of governments but the struggle to contain the demands of interest groups for protection. Because of these demands, it may be advantageous for the government to limit its own freedom of action in order to avoid being forced into moves that hurt the economy, even if the government thereby loses the opportunity to pursue some desirable trade policies.

18. "Boeing: Getting in Its Retaliation First," The Economist, January 28, 1984, pp. $66-68$. 
Taken together, these arguments form a strong case against any active attempt by the U.S. government to play a strategic role in international competition and in favor of restricting our trade policy to a legalistic response to problems such as foreign dumping and proved subsidy. There remains, however, the question of response to foreign governments. Although the United States should not try to play this kind of strategic game, it might want to respond forcefully when other countries do so. The next section examines the extent to which foreign targeting represents a strategic industrial policy.

\section{STRATEGIC POLICY IN PRACTICE}

The essence of strategic industrial policy is that government intervention allows targeted industries to earn excess returns. Have foreign targeted sectors actually achieved high returns on investment? The answer may seem surprising. None of the most famous targeted sectors has been highly profitable, or indeed even of average profitability.

Aircraft is the clearest case. As documented in the appendix, massive government financial support was needed to make Airbus Industrie a serious competitor to Boeing, and continued support seems necessary to keep Airbus aloft. Steel has been a low-return business in Japan and elsewhere around the world since the early 1970s. Even before the bottom fell out of the steel market, returns on investment in Japanese steel were below the average for Japanese manufacturing. ${ }^{19}$ Because Japanese plants built during the late 1960s and early 1970s have lower operating costs than the older plants of their U.S. and European rivals, Japanese steel has had a competitive advantage in the depressed world market; but the eventual rate of return on the heavy Japanese investments of 1966-72 must have been quite low.

Finally, the recent Japanese successes in semiconductors have so far been Pyrrhic victories as measured by financial returns. Japan's semiconductor firms in general have low profits, and in particular the Japanese penetration of the market in 64K RAMs (semiconductors with 64,000 bytes of random-access memory) was bought at the expense of a price war that has not allowed much return so far. ${ }^{20}$ The hope of the Japanese

19. See Paul R. Krugman, "Targeted Industrial Policies: Theory and Evidence," in Industrial Change and Public Policy, pp. 145-46.

20. See Michael Borrus, James Millstein, and John Zysman, "Responses to the Japanese Challenge in High Technology: Innovation, Maturity, and U.S.-Japanese Com- 
firms is presumably that they will eventually be able to use the market position they have gained to realize profits. As discussed below, however, it is not clear whether a large market share in random-access memory chips has much bearing on competition in more profitable areas, and it is at least a strong possibility that Japan's investment in $64 \mathrm{~K}$ RAMs will never be recovered.

There may be a less well known industry that was targeted and earned high returns, but I am not aware of one. This dearth of high profits is surprising. In theoretical models, policies qualitatively similar to those of the European governments supporting Airbus or that of the Japanese government with regard to electronics could act as strategic tools which allow home firms to earn large returns. Why, then, are there no examples of high returns?

The probable answer is that strategic industrial policies are unlikely to be successful unless governments are actually trying to play the game; but in practice governments are not so clear headed. European support of Airbus is based on a mixture of motives, including prestige, employment, presumed externalities, and so on. Japan's industrial policy is in principle an attempt to anticipate future comparative advantage; in practice, apart from the inherent difficulties of doing this, political considerations and a variety of motives probably dominate decisions. These mixed motives mean that the policy deftness envisioned in the theory has not actually been visible.

\section{Foreign Targeting and Technology}

Even those most skeptical about the alleged dangers of foreign industrial policies get a little nervous about the possible effects of foreign targeting on U.S. technological progress. Over the last decade the hightechnology industries have appeared to become increasingly important to the U.S. economy, yet at the same time the technological superiority of the United States over other countries has appeared to be eroding. One cannot help feeling some concern about whether the policies of other countries will somehow undermine the U.S. technological base. To make this concern more than a vague unease, however, we need to

petition in Microelectronics," Berkeley Roundtable on the International Economy (July 1983), pp. 5-7; and 'Japan's Strategy for the '80s,' Business Week, December 14, 1981, pp. 61-62. 
place it into a coherent economic framework. Why should high-technology sectors be treated any differently from other sectors? What, if anything, makes the production of computers a more desirable activity at the margin than production of textiles?

The obvious answer is that innovative sectors are likely to generate positive externalities. In many cases, the benefits generated by innovative firms cannot be fully appropriated by these firms: other firms can imitate or learn from the pioneer's experience. As a result, markets may do too little investment in knowledge, or more generally in knowledgegenerating industries. The recognition of this likely externality motivates government support for research and could also be used to justify at least some kind of an industrial policy. The argument would be that foreign targeting of innovative industries such as aircraft and semiconductors is leading the United States to invest less in areas in which social returns are much larger than private returns and consequently slowing U.S. growth. However, analyzing the effect of foreign targeting on U.S. technology requires more than a distinction between innovative and noninnovative sectors; the characteristics of the knowledge generated are of crucial importance. Before turning to these issues, it will be useful to begin with a review of some aggregate measures of competition in the high-technology area.

\section{TRENDS IN TECHNOLOGY-INTENSIVE TRADE}

Statistical analysis of international competition in innovative sectors is necessarily based on imperfect proxies. The most common approach has been to rank industries by some measure of research intensity and to aggregate industries high on the ranking into a "high-technology" or "technology-intensive" sector. Inevitably, research intensity is measured by inputs rather than outputs; relevant inputs include R\&D expenditure as a share of value added or the proportion of scientists and engineers in the work force.

There are two serious problems with these input measures as proxies for technology intensiveness. First, the measures capture formal research activity, which could be misleading in industries where learningby-doing is important or where innovative firms are too small to have a formal distinction between research and other activities. Second, the calculations focus on a fixed set of industries over time. This could be misleading insofar as innovative industries mature and become less 
Table 4. Indicators of Competitive Performance in High-Technology Exports, Selected Countries, 1970 and 1980a

\begin{tabular}{|c|c|c|c|c|c|}
\hline Year & $\begin{array}{l}\text { United } \\
\text { States }\end{array}$ & Japan & France & $\begin{array}{l}\text { West } \\
\text { Germany }\end{array}$ & $\begin{array}{l}\text { United } \\
\text { Kingdom }\end{array}$ \\
\hline & \multicolumn{5}{|c|}{$\begin{array}{c}\text { Share of country's high-technology exports in its total } \\
\text { manufacturing exports (percent) }\end{array}$} \\
\hline 1970 & 28.3 & 15.9 & 13.2 & 13.2 & 19.1 \\
\hline \multirow[t]{2}{*}{1980} & 28.9 & 13.5 & 14.5 & 13.8 & 22.7 \\
\hline & \multicolumn{5}{|c|}{$\begin{array}{c}\text { Share of country's high-technology exports in total OECD } \\
\text { high-technology exports (percent) }\end{array}$} \\
\hline 1970 & 37.8 & 13.1 & 8.3 & 18.5 & 12.7 \\
\hline \multirow[t]{2}{*}{1980} & 32.1 & 12.8 & 9.4 & 17.8 & 15.0 \\
\hline & \multicolumn{5}{|c|}{ Relative importance of high-technology exports $(\text { ratio })^{\mathrm{b}}$} \\
\hline 1970 & 2.13 & 1.20 & 0.99 & 0.99 & 1.44 \\
\hline 1980 & 2.05 & 0.96 & 1.03 & 0.98 & 1.61 \\
\hline $\begin{array}{l}\text { Source: } \\
\text { Trade," } \\
\text { Economic } \\
\text { various is } \\
\text { a. High } \\
\text { U.S. man } \\
\text { b. High }\end{array}$ & $\begin{array}{l}\text { erage in } 1 \\
\text { share of }\end{array}$ & $\begin{array}{l}\text { C. Micha } \\
\text { J.S. Depa } \\
\text { Trade b } \\
\text { git SITC } \\
\text { try's man }\end{array}$ & $\begin{array}{l}\text { Howard } \mathrm{F} \\
\text { Labor, } 19 \\
\text { dities, Mar } \\
\text { that had at } \\
\text { exports di }\end{array}$ & $\begin{array}{l}\text { "Trends in T } \\
\text { e data are fro } \\
\text { maries, Serie } \\
\text { o-sales ratio } \\
\text { high technolo }\end{array}$ & $\begin{array}{l}\text { logy-Intensive } \\
\text { ganization for } \\
\text { Paris: OECD), } \\
\text { han twice the } \\
\text { hare of OECD }\end{array}$ \\
\hline
\end{tabular}

dynamic or industries with low innovation develop new branches with high rates of technological change (such as fiber optics in the glass industry). Although patterns of trade in research-intensive products have become a major preoccupation of government agencies both in the United States and Europe, ${ }^{21}$ the statistics show little evidence of any major shifts in the U.S. position from 1970 to 1980.

Table 4 uses a narrow definition of technology-intensive industry (a ratio of $R \& D$ costs to sales more than twice the 1970 U.S. manufacturing average) to compare the high-technology trade of five major industrial countries in 1970 and 1980. The first part of the table shows, unsurprisingly, that in both years high-technology exports were a much greater share of manufacturing exports for the United States than for any of the other countries. More surprising, perhaps, is the fact that Japan reduced its specialization in high-technology products. The reason is that much of Japan's export success in the 1970s was in traditional, mediumtechnology industries such as autos.

21. See Commission of the European Communities, The Competitiveness of the Community Industry (Luxembourg: CEC, 1982), and U.S. Department of Commerce, International Trade Administration, An Assessment of U.S. Competitiveness in High Technology Industries (Washington, D.C.: ITA, 1983). 
That high technology represents a low share of Germany's exports and a high share of U.K. exports is also somewhat surprising. It is possible to think of some intuitive justifications. Germany's export strength has been built around the traditional core of heavy industries with little visible presence in glamorous, high-technology areas such as computers or aircraft. The United Kingdom, by contrast, has a reputation for being good at creating ideas but poor at maintaining production, so it makes sense for Britain to be relatively successful in areas where the ratio of skilled technicians to production workers is high. These European data indicate that there is is no simple association between specialization in high technology and overall economic success.

The second part of table 4 shows that only for the United States did high-technology exports decline noticeably as a share of OECD hightechnology exports. This change is viewed by some as cause for alarm; the worry is that at some point high technology in the United States will go the way of autos and consumer electronics.

Some decline in the U.S. share of world high-technology exports would be expected given the resource shifts described in table 1 . The question is whether the decline in the U.S. share of technology-intensive goods has been part of a general process or whether something special has been going on. The last part of table 4 suggests that for the United States the behavior of the high-technology sector has not been unusual. By measuring the share of high-technology products in the manufacturing exports of each country (the first part of table 4) and dividing it by the same measure for the OECD as a whole, the last part of table 4 shows very little change in the degree of U.S. specialization in high technology compared with that of other countries.

\section{EXTERNALITIES AND INTERNATIONAL COMPETITION}

Although there is little evidence of any wholesale erosion of U.S. technology-intensive sectors by foreign competition, government-sponsored or otherwise, there are certainly innovative industries where foreign industrial targeting has reduced U.S. sales. We might be tempted to assume that foreign targeting in these sectors has slowed U.S. technological progress. A careful review of the theoretical arguments, however, suggests greater caution.

In the standard analysis of the economics of innovation, the key 
concept is the degree of appropriability. How much of the benefit of innovation can be captured by the innovator? Where benefits are hard to appropriate, there is a presumption that the social return to investment in knowledge will be higher than the private return, and that firms will therefore underinvest. By contrast, where the benefits of innovation are easily appropriable, there is no presumption of inadequate investment. Indeed, in an imperfectly competitive industry, firms might well invest too much in $R \& D$ from a social point of view because of their attempts to use such investment as a strategic move to deter entry by potential competitors. We should be concerned, therefore, not with all innovative activities but only with those that generate knowledge whose benefits are hard for firms to appropriate.

Even this distinction is not enough in this context. Suppose that a foreign government subsidizes an industry in which firms are known to generate substantial technological spillovers. To the extent that this leads U.S. firms to invest less in developing knowledge, the United States will lose some external benefits. But there is no reason why external effects must stop at national borders, and the United States may benefit from the knowledge gained by foreign firms. If the knowledge generated by foreign firms can be used by U.S. firms, the foreign targeting need not hurt the United States; it may well help by leading to more world-wide investment in knowledge.

It is apparent, then, that we need to distinguish innovations by how they diffuse. At one extreme we might have innovations which can be wholly internalized by firms. Examples of this might be details of manufacturing technology which can be kept secret because only a few people need know them. At the other extreme would be innovations which can be imitated by anyone with sufficient skill, regardless of his location. The obvious example is product design, which can often be "reverse engineered" from samples. Between these cases would be knowledge that cannot be held closely by firms, but which diffuses in a way that limits its spread. The most likely example here is knowledge that passes by word of mouth or exchange of personnel and is thereby restricted to particular geographic locations or cultural units.

Under what circumstances would foreign targeting of an innovative industry not concern the United States? It should be indifferent or perhaps even grateful if the kind of innovation being encouraged is of either extreme type. If firms can easily appropriate the benefits of their 
own investment in knowledge, government support does not pose an externality issue. It could in principle raise the issue of strategic policy; but as discussed above, the theoretical concern over strategic industrial policy seems to have little basis in experience. So foreign support for highly appropriable R\&D is not a likely source of serious injury.

At the other extreme, foreign targeting of activities where knowledge easily diffuses internationally is also not a source of injury to the United States. Indeed, if it raises world investment in activities that yield positive externalities, the United States may well benefit. If other countries benefit from U.S. research into genetics, could not the United States benefit from Japanese research on computer design?

Damage from foreign targeting is likely to arise in the intermediate range, where technological change involves creation of a pool of knowledge that is not easily held within firms but tends to stay within national boundaries. Only in this case is it probably true that foreign countries gain at U.S. expense when they target innovative industries. How can we identify these cases? Aggregative statistics on R\&D, employment of scientists and engineers, and so on do not illuminate this issue. It seems necessary to focus on particular cases and rely on qualitative descriptions. In what follows I focus on the example of semiconductors.

INNOVATION AND APPROPRIABILITY

IN THE SEMICONDUCTOR INDUSTRY

The semiconductor industry is a dramatically successful generator of innovation; Japan's challenge to the United States has been a source of considerable alarm. To assess whether this concern is justified, however, we need to analyze the effects of Japanese competition on externalitygenerating innovation.

It is an oversimplification, but perhaps not too misleading, to say that there are three different kinds of knowledge generated in the semiconductor industry. The first is detailed production knowledge, particularly in the manufacture of semiconductor chips. The second is product design, which is essentially the layout of chips. The third is less definable, but of crucial importance: the knowledge about how to create knowledge, that is, the know-how needed to carry out other innovations.

There are strong learning-curve effects in semiconductor manufacture that have mainly to do with reliability. When a new semiconductor 
manufacturing facility is opened, it will normally produce mostly rejects; only over time does the yield of usable chips rise. Many estimates suggest that every doubling of cumulative production leads to an increase of 20 to 30 percent in the yield of chips. ${ }^{22}$ This learning-through-production does not diffuse easily to other firms. In fact, chip production experience appears to be so specific and undefinable that there is little spillover even between different plants of a single firm. Thus the knowledge generated by production experience in semiconductors is of the first type, internalized knowledge with no externalities.

The characteristics of the second type of innovation in semiconductors, product innovation, are in many respects opposite those of production experience. Where production experience is unstructured and difficult to define, product design is literally hard wired. Production experience accumulates gradually over time; product design comes from front-end, formal research. And crucially in our context, product design can be imitated or learned directly from the hardware.

Last, the third kind of knowledge, knowing how to innovate, probably involves some things learned by word of mouth and some personal knowledge carried between firms by movement of individuals: the tendency of innovative firms to be founded by defectors from other firms is legendary. There is also probably an externality involved in the creation of a specialized labor market, which gives firms the needed flexibility. While the importance and nature of diffusion of this kind of knowledge cannot yet be directly measured, the economic geography of the U.S. high-technology sector, in which many firms are clustered near Boston and in California's Silicon Valley, seems to suggest that important externalities do not diffuse easily over long distances.

If this characterization of the relationship between innovation and appropriability in semiconductors is correct, then there is a rough correspondence between the three types of knowledge described here and the three-way distinction among types of innovation that is needed to assess whether foreign targeting hurts U.S. technological progress. The learning curve in chip production is a firm-specific type of knowledge generation, which poses issues of imperfect competition and strategic behavior but not of external economies. Product design is not easily

22. See U.S. Congress, Office of Technology Assessment, International Competitiveness in Electronics (November 1983), p. 76. 
appropriable, but the diffusion probably takes place about as easily across national boundaries as between firms in the same country, that is, the externality is international. Finally, the generalized innovative capacity embodied in personal knowledge, informal communication, and a specialized labor market involves externalities that are largely confined within national boundaries.

Has Japanese targeting in semiconductors focused on those activities that generate localized external economies? In principle, it could do this because localized externalities are probably quite important in the semiconductor industry; that the actual targeting has had this effect is doubtful.

The major Japanese effort and the main success as measured by market share has been in random-access memories (RAMs), which are different from many other semiconductor products in that there is a relatively large market for standardized items. Product development, while expensive, is a one-time, front-end cost rather than a continuous process of customization and development for particular uses. Low manufacturing costs and reliability are more important, and flexibility and design skills less important, than in other semiconductor lines. ${ }^{23} \mathrm{In}$ other words, manufacture of RAMs yields firm-specific manufacturing knowledge and internationally available product design, but not much in the way of country-specific knowledge not appropriable by firms. Japan has thus targeted precisely that part of the semiconductor industry least likely to yield country-specific external benefits.

This may sound too good to be true, but it is not an accident. Japanese industrial policy is in large part a ratification of the direction in which the private sector would be going in any case. Other things held equal, Japanese firms will be most likely to succeed where they do not suffer a disadvantage because of the external economies generated by an established U.S. industry. Thus a consideration of expected private returns tends to lead Japanese competition away from the areas where firms based northwest of Boston or south of San Francisco have an extra advantage. If Japanese industrial targeting were clearly based on the distinction between private and social returns it might oppose this tendency; but it is not.

It might still be argued that the U.S. loss of market share in RAMs

23. See, for example, "Japan's Strategy," pp. 63-64. 
will ultimately imperil U.S. capacities in other parts of the semiconductor industry. One of the most influential studies of the industry argued that the cash flow from the RAM business was essential to finance innovation in other products. Why such a capital market failure should exist in Japan is unclear, but it does not exist in the United States. The same authors, in a later reconsideration, suggest that the United States might still be able to win the competition in the more sophisticated, and currently more lucrative, custom-chip market even without a commanding position in RAMs. ${ }^{24}$

The arguments of this section can now be drawn together. U.S. technological capacity is probably the most likely candidate for concern about the effects of foreign competition. As Japan and Europe become competitors with the United States in such high-technology areas as electronics and aircraft, it becomes necessary to take a close look at the theoretical basis for this worry and at the evidence.

The primary message of our analysis is that a careful assessment is important. All innovation is not the same in its international implications, and only by examining the particular features of an industry can crucial distinctions be made. An examination of one particular industry, semiconductors, illustrates the point: combining economic analysis with information about the industry yields much less cause for concern than most popular discussions suggest. One industry is not the whole, but this review of the most cited industry indicates the need for caution before sounding the alarm.

\section{An Overall Assessment of Foreign Targeting}

Have U.S. trade and the structure of U.S. industry been importantly shaped by the policies of other governments? If so, has the U.S. economy been seriously hurt by these policies? The answer to the first question appears to be yes, although to a more limited extent than many Americans seem to think. The answer to the second appears to be probably not, given our understanding of the economy.

Since these conclusions are bound to be controversial, it is worth reviewing the analysis. Most objective studies find that many, though

24. Borrus, Millstein, and Zysman, International Competition, and "Responses to the Japanese Challenge.", 
by no means all, of the sins of which foreign governments are accused melt away under close examination. Government financial support to industry is smaller than widely believed, except for some admittedly important fields such as aircraft. Restrictions on market access are or have been significant in a number of areas, and there is a reasonable case in theory for the argument that protected home markets can serve as a springboard for later or even concurrent export success. But in many of the major areas in which foreign countries have gone on from initially protected home markets to later export success, such as autos and steel, the lags have been long enough to make tenuous the connection between past protection and current success.

Nonetheless, there are enough sectors where foreign targeting may have made an important difference, especially in high-technology areas, to believe that targeting has helped shape U.S. trade. But has this hurt the U.S. economy? If it simply leads to a somewhat different allocation of resources in the United States why would foreign targeting be a problem? I have clarified the arguments that claim it is a problem and looked for evidence that would support or refute those arguments.

The simplest argument is that foreign targeting leads to increased unemployment in the United States or to worsened terms of trade. There is quite simply no evidence that it has increased unemployment. And the downward trend in the U.S. terms of trade through 1980 has been moderate and explainable from fundamental trends in foreign economic development relative to that of the United States. Since 1980, the U.S. terms of trade have actually improved.

A more subtle argument is that foreign targeting has displaced U.S. workers from industries where, for institutional reasons, the wage rate and marginal productivity are high. However, by and large the U.S. industries that have lost out to foreign competition have mainly had low rather than high wages. The exception over the last decade has been the automobile industry-steel also would have been in this category had it not been effectively protected-and there the success of imports has not come from targeting.

A third potential source of damage from foreign targeting could be a redistribution of profits from U.S. to foreign firms through protective marketing strategies aimed at discouraging competition in oligopolistic industries. Although this is an interesting theoretical argument, the fact is that few targeted industries have earned high, or even normal, rates of return. 
Last, foreign governments could be undercutting U.S. technological progress by targeting sectors that yield important externalities. Some foreign targeting has been aimed at innovative, high-technology sectors such as aircraft, telecommunications, and electronics. Although no broad attempt to assess the impacts of these policies on U.S. technology was made, the case study of semiconductors suggests that even where worries about lost technological capacity seem most justified, the actual results of foreign government action have not been seriously harmful to the United States.

The broad conclusion is that the industrial policies of foreign governments have not been a serious problem for the United States. This does not mean that one country's industrial targeting can never hurt another, or that the United States should be complacent about any future foreign policies. But the actual policies followed by our major industrial competitors do not appear to have had important malign effects.

This leaves the question of why there is so much support for the view that the actions of foreign governments are the cause of many of our problems. The answer is unfortunately depressingly obvious: over the past decade U.S. economic performance has been disappointing by any standard, and it is simply easier to blame foreigners than ourselves.

\section{APPENDIX}

\section{Foreign Targeting in Selected Industries}

THE FOLLOWING BRIEF SURVEY describes the supports offered by foreign governments in five key manufacturing sectors: aircraft, steel, telecommunications, semiconductors, and machine tools. It is intended as background for the general discussion in the text.

The policies followed in each industry are grouped into three categories. The first is financial support: subsidies, low-interest loans, tax advantages, and so forth. The second is restricted market access: creation of a privileged "safe haven" for domestic firms, whether through explicit protection, preferential procurement, or tacit closure of markets. 
The third is rationalization: government intervention in market structure, including cartelization, promotion of mergers, and encouragement of collaborative research.

\section{Aircraft}

The aircraft industry is the clearest example of foreign targeting that adversely affects U.S. firms. The United States has traditionally dominated the production of large commercial aircraft but has now been challenged by Airbus Industrie, a consortium jointly owned by several European governments. The key to the Airbus challenge is government financial support. Over the period 1968-82 Airbus received subsidies totaling nearly $\$ 2.5$ billion..$^{25}$

Market access is also an issue because European state-owned carriers evidently form a privileged market for Airbus planes. Perhaps surprisingly, however, the U.S. aircraft industry has not stressed market access as a key complaint. This probably reflects two facts. First, the European market is much smaller than that of the United States; regulation has kept air fares high, and distances are short, so that air travel is much less common than in the United States. Second, much of the growth of the market, which generates demand for additional rather than only replacement aircraft, has occurred in third countries. Thus the U.S. industry has focused its attention more on financial assistance than on access to markets. ${ }^{26}$

\section{Steel}

There are two separate steel stories. In Japan steel was, until 1973, a growth industry, its growth perhaps aided by government policies. In Europe steel has been a declining industry, a fact that implies a very different role for policy. I will discuss the two cases in turn. ${ }^{27}$

25. This comes from unpublished data supplied by the Office of the U.S. Trade Representative.

26. See John Steiner, "Technical and Financial Imperatives: What's Ahead," paper presented at the 1982 annual meeting of the American Institute of Aeronautics and Astronautics.

27. There is a good discussion of Japanese steel policy in ITC, Foreign Industrial Targeting. Also see Bethlehem Steel Corporation and United States Steel Corporation, 
Japan's steel industry received considerable financial support from the government during the 1950s. Some low-interest loans and tax advantages continued during the 1960s and early 1970s, but the amounts of subsidy appear to have been modest. Until the early 1960s Japan had explicit protection of its steel industry. By about 1960 Japan had become competitive in steel and would have been a net exporter even with an open market. It appears, however, that foreign entry into even limited market segments was prevented by tacit closure of Japan's distribution system. The Japanese government several times during the 1960s attempted to organize steel industry cartels; their purpose, however, appears to have been to limit the growth of the industry rather than promote it.

In Europe, a troubled steel industry has been the target of all three kinds of policy. Financial support has taken several forms. In France the government engineered a complex scheme which effectively canceled the industry's debt. In several countries government-owned steel firms have operated with earnings insufficient to service their debt. The U.S. Commerce Department has found subsidies ranging from 13 to 26 percent for some producers. What is unclear, however, is whether this financial support has actually provided incentives for increased output or competition with the United States. By and large financial support seems to have been more a bailout for bondholders than a subsidy for production or for the creation of new capacity.

The European steel industry is protected from outside competition by "voluntary" limitations on Japanese sales. These limitations are an essential ingredient in the third type of policy, rationalization, which in this case takes the form of a steel cartel. A principal purpose of this cartel, which sets minimum prices and output quotas, has been to protect the established, high-cost producers in Europe from the internal competition of small, low-cost Italian mills.

Taken together, it is hard to construe European policies as being the source of a competitive challenge to the U.S. industry. In the case of

Japanese Government Promotion of the Steel Industry: Three Decades of Industrial Policy (Washington, D.C.: BSC and USSC, 1983). For European steel policy see Joint Economic Committee, Monetary Policy, Selective Credit Policy, and Industrial Policy in France, Britain, West Germany, and Sweden, 97 Cong. 1 sess. (GPO, 1981); Labor-Industry Coalition for International Trade, International Trade, Industrial Policies, and the Future of American Industry (Washington, D.C.: LICIT, 1983); René Joliet, "Cartelisation, Dirigism, and Crisis in the European Community," The World Economy, vol. 3 (January 1981), pp. 403-45. 
Japan, the combination of financial support and protection certainly did encourage the growth of the steel industry before 1960 . The question is whether one can attribute the U.S. industry's competitive difficulties to Japanese policies of almost twenty-five years ago, a time when Japan's production was far less than that of the United States. In the absence of very powerful dynamic scale economies-which seem unlikely in a mature industry like steel-this is a hard case to make.

\section{Telecommunications}

In all the industrial countries the major consumers of telecommunications equipment are either state-owned firms or regulated monopolies. These firms either produce their own equipment or have long-term relationships with domestic firms. This allows "userfunding'" of research and development out of revenues from the provision of services. It also means that there is not an open market in telecommunications equipment. All large industrial countries have negligible imports of hardware; only the small European countries, whose markets do not allow self-sufficiency in items with large economies of scale, have sizable import shares. A remarkable fact is that there is very little trade in telecommunications equipment even within the European community, where formal barriers to trade are absent. Until recently the U.S. market has also been virtually free of imports. ${ }^{28}$

The main export trade of industrial countries is therefore to less advanced countries; not surprisingly, exports are generally small relative to home-oriented production. The only exception among large countries is Japan, which has fairly sizable trade surpluses.

It is difficult, however, to argue that the protected domestic market has played much of a role in Japan's export success in telecommunications, for two reasons. First, Japan is not unique in having a closed domestic market. Second, and more important, the bulk of Japan's "telecommunications" exports are apparently such items as CB radios; consequently they are more similar to consumer electronics than to what we would normally think of as telecommunications equipment, and a different sort of product from that for which Nippon Telephone and

28. See Organization for Economic Cooperation and Development, Telecommunications Equipment Industry Study (Paris: OECD, 1981), especially appendix table A3. 
Telegraph provides a privileged market. ${ }^{29}$ The telecommunications equipment industry, then, is not one in which countries appear to have used a protected domestic market as a springboard for exports. There has probably, however, been a strong element of old-fashioned protection. Telecommunications is a high-technology industry, and the United States would probably have run substantial trade surpluses in it over the postwar period if trade had been truly free.

\section{Semiconductors}

The case of semiconductors has been hotly disputed and has acquired great symbolic importance. Although the United States continues to produce about 60 percent of the world's output of semiconductors, and Japanese imports account for only 6 percent of the U.S. market, ${ }^{30}$ Japan's success in capturing a dominant position in the RAM (randomaccess-memory) portion of the semiconductor industry has greatly alarmed many in the United States. Partly this is because, for the first time, Japan appears to have won the fight in a new product rather than to have imitated the United States with a lag; partly it is because semiconductors are widely regarded as a key sector, as discussed in the text.

Japan explicitly targeted semiconductors beginning in the early 1970s, with tariffs and import restrictions as its major tools. In the mid-1970s these formal barriers were dismantled under U.S. pressure. Nonetheless, imports of U.S. semiconductors did not rise as a share of Japanese consumption. In fact, Japan began to export semiconductors in substantial quantities to the United States. In 1979 a capacity shortage in the United States offered Japanese firms an opportunity to make a substantial penetration in the market for $16 \mathrm{~K}(16,000$-byte) RAMs. Then in 1981 Japanese firms shocked the U.S. industry by taking most of the open market in a new product, $64 \mathrm{~K}$ RAMs. ${ }^{31}$

There are a number of bitterly disputed questions about the interpretation of this history. The most important is the extent to which the semiconductor industry, or more particularly that part in which Japan

29. Ibid, p. 19.

30. ITC, Foreign Industrial Targeting, p. 219.

31. Borrus, Millstein, and Zysman, International Competition, pp. 105-06, and "Response to the Japanese Challenge,"' p. 67. 
has achieved a large market share, is actually "key." If possession of a dominant role in the semiconductor industry is, as many believe, essential to the U.S. economy, the United States should react strongly to foreign challenges whether or not they are the result of government policies. Even reserving that issue, however, two major uncertainties remain. First, is market access in semiconductors still restricted in Japan? Second, how important has a protected domestic base been to the Japanese industry's growth?

It has been widely alleged that the Japanese semiconductor market is still essentially closed despite the absence of formal barriers. The major purchasers of semiconductors in Japan are also the major producers, and they are alleged to collude, perhaps with discreet government encouragement, to buy from each other rather than from abroad. The main evidence for this is the failure of the U.S. share of Japan's market to rise after formal liberalization of trade, and the dynamics of changes in market share.

The failure of the U.S. market share to rise does suggest that formal liberalization made little difference. Anecdotal evidence suggests that a "buy-Japanese" mentality exists, and the structure of the Japanese semiconductor market does allow some scope for this to restrict trade patterns. For perspective, however, it is useful to recall that Japanese exports take only 6 percent of the U.S. market, primarily in the single product area of RAMs. Thus strong buyer-supplier relationships and a tendency to rely on local sourcing need not reflect government policy.

The dynamics of change are a more subtle issue, and are also closely tied to the question of the importance of a protected home market. Two influential studies, a report prepared for the Joint Economic Committee of the U.S. Congress and a report prepared for the Semiconductor Industry Association, have argued that the recent pattern of sudden changes in market share demonstrates both the de facto closure of the Japanese market and that closure's crucial role in competition. ${ }^{32}$ The congressional report points to the tendency of Japanese producers to take over the whole domestic market as soon as they are able to produce a product and argues that the advantage of experience that U.S. producers have should instead make the process more gradual. The industry report points to the aggressive pricing of Japanese firms, running ahead

32. Borrus, Millstein, and Zysman, International Competition, and Semiconductor Industry Association, The Effect of Government Targeting on World Semiconductor Competition (Washington, D.C.: SIA, 1983). 
of cost reductions, as something unsustainable without the assurance of a domestic "safe haven."

The problem with the congressional and industry arguments is that the same factor that makes market access of great potential importance, the role of dynamic scale economies, would produce sudden shifts of market share even in the absence of protection. Learning curves provide an incentive for firms to follow "Boston Consulting Group" strategies, involving price cuts ahead of cost reductions and efforts to achieve large increases in market share even if this involves initial losses, regardless of whether firms have a protected home base. It would be a mistake to take the view that rapid changes in international competition are themselves evidence of unfair foreign trade practices.

The Japanese semiconductor market was, however, certainly protected until about eight years ago, and the semiconductor industry offers a classic example of dynamic scale economies. So whether or not Japan's market is still tacitly closed, past protection can be presumed to partially account for the Japanese industry's current competitive strength.

At about the same time that formal protection for semiconductors was lifted, Japan began attempting to promote the semiconductor industry through subsidized and government-encouraged collaborative research, especially the famous very large scale integration program. Opinions about the importance of that program to Japan's success in RAMs vary, but it is at least possible that such programs are an important factor in Japan's high-technology growth.

\section{Machine Tools}

Recently Japan's export success in numerically controlled machine tools has become a major political issue in the United States. ${ }^{33}$ The scope of the issue is not comparable to that in semiconductors, but the basic outline of Japanese policy is quite similar. There has been some government financial support, but the sums have been quite modest. Considerable protection was provided until the mid-1970s, but formal protection is now minimal. And collaborative R\&D of uncertain importance has taken place with government encouragement.

33. For an account of Japanese targeting of machine tools, see ITC, Foreign Industrial Targeting, pp. 141-47. 


\section{Comments and Discussion}

Carlos F. Diaz-Alejandro: I liked Paul Krugman's paper very much, not only because of its conclusions, but also because of the approach he takes to dissecting possible arguments for protection. Those arguments represent very old wine in shiny new bottles. The paper is an elegant essay in development economics and an exercise in the economics of the second-best.

There are three lines of thought which could lead to a case for protection. The first one rests on dynamic scale economies, generated by learning effects. As Krugman recognizes, this is an elaboration of the old infant-industry argument, known to Alexander Hamilton and to innumerable nineteenth-century German economists of the historical school. As it behooves the times, the argument is now presented in a sophisticated and algebraic fashion, but its essence is similar to arguments used to defend official encouragement of import-substituting industrialization in Latin America.

The second line of thought may be called the Manolescu thesis, in honor of the celebrated Romanian fascist economist. Everett Hagen refined this argument for protection, which rests on a wage distortion between urban and rural sectors in developing countries. Krugman lapses from his customary lucidity on the application of this argument to the United States; it is unclear what alternative equilibriums are being contrasted in his comparative static exercise.

A third line of argument, murkily foreshadowed in the writings of underground and peripheral economists, rests on the theory of strategic industrial policy. Governments and large corporations can preempt markets and keep others from going in without resort to visible trade restrictions. During the 1950s and 1960s, using related arguments, many 
observers both in Europe and in developing countries claimed that U.S. corporations had unfair trade and investment advantages as they were big enough to engage in strategic industrial policy on their own without explicit government support. Indeed, it could be argued that the desire to counter such advantages motivated European and other governments during the 1950s and 1960s to support home corporations, which were perceived as being too weak to resist on their own the strategic thrusts of U.S. giants.

Krugman argues that while these lines of thought can generate protectionist conclusions under some assumptions, which take us to second- and third-best possibilities, a careful evaluation of U.S. conditions indicates that those logical possibilities have no significant likely counterparts in reality. The experience of semi-industrialized countries, where plausible protectionist arguments have been grossly abused in practice, reinforces this cautious attitude against leaping from secondbest theoretical arguments for protection to the real thing. The policy force of these arguments is far weaker for the United States than for developing countries, for three reasons.

First, U.S. firms have as their habitat the largest home market in the world. No foreign firm can have the security of access to this market that the U.S. firm has, and thus U.S. firms have an unparalleled head start in securing dynamic scale economies. Second, insofar as serious market imperfections exist within the United States, such as wage distortions and learning externalities, the U.S. government can count on a vast array of policy instruments to tackle those distortions directly rather than using the clumsy instruments of trade policy to remedy them. Few countries in the world can boast the array of policy instruments at the disposal of the U.S. federal government. Third, U.S. firms are larger, on average, than those in the rest of the world, and in many industries very much larger. As Krugman notes for the case of Boeing, this allows many U.S. firms to engage in strategic industrial planning on their own, without government action, to a much greater extent than foreign firms can.

If the United States were to restrict international trade by relying on the lines of thought analyzed by Krugman, it would be hard to imagine a country where those arguments would not apply a fortiori. If the United States is no neoclassical paradise, imagine what could be said about Argentina, or Brazil, or South Korea. 
Concern with how arguments for protection "internationalize" leads us to a topic left aside by Krugman's paper: how adequate are present international trade rules for handling trade disputes and restrictions in which the arguments discussed above play a prominent role?

If one starts with the simplest case for free trade, based on perfect markets and atomistic firms and countries, something like the General Agreement on Trade and Tariffs is not easily understood from a purely economic viewpoint. What is the point of an international treaty that bans shooting yourself in the foot? But countries are not atomistic, and the optimum tariff argument teaches that trade restrictions could benefit one country at the expense of the rest of the world, unless other countries retaliate. On this basis, the case can be made for the GATT as tariff disarmament to prevent trade warfare.

The theory of strategic industrial policy also strengthens the case for some kind of GATT; oligopolistic behavior may make a firm and its country better off, but it can also unleash trade warfare. The problem is that the GATT as we know it deals with tariffs and other overt trade restrictions better than it deals with industrial policies that impact on international trade in less traditional ways. Krugman's paper reinforces what many observers have been arguing: the GATT should be reformed and expanded to better take into account industrial policies and related behavior impinging on international trade. In designing the expanded rules, the theoretical complications discussed in Krugman's paper will be better guides than models with atomistic actors. To give but one example that also shows the difficulty of deriving operational rules from the new theoretical models, if today's pricing is anticipating future relative cost changes rather than today's cost, dumping rules cannot be based on the Marshallian theory of the firm.

Expanding the GATT rules on trade and industrial policy may not be enough. The theory of strategic industrial behavior smartly packages old fears of excessive market power by large corporations. Whether the large firms are "ours" or "theirs," some kind of international antitrust mechanism may be needed.

The emotional appeal of protectionism now exploits feelings of vulnerability vis-à-vis foreign governments and firms and excites the urge to seek nationalistic redress against foul and unfair foreigners. Better international rules binding and monitoring governments and large firms may go a long way toward defusing that emotional appeal. 
Finally, I share Krugman's bafflement about why, against all quantitative evidence, so many politicians and other observers in this country perceive the United States as declining across the board vis-à-vis other industrialized and semi-industrialized countries. The evidence argues against the possibility that the United States confronts a Kindlebergian climacteric, like that experienced by the United Kingdom during the 1880s. The claims of industrial decline seem more like the claims of a missile gap in the late 1950s and early 1960s.

Robert Z. Lawrence: Should the United States get tough with foreign targeting practices? In this paper, Paul Krugman finds little evidence that these policies damage the United States and therefore decides that the answer to this question is no.

This is a very difficult paper to write. It is usually hard to prove something does not exist; as Krugman acknowledges, since even foreign governments do not know the effects of what they are doing with much precision, it is especially hard to do it convincingly in this case. The idea has become increasingly popular that U.S. firms cannot compete successfully in international trade because they do not receive as much government assistance as do foreign firms. The idea cannot be dismissed lightly, because if enough people really believe it, the U.S. commitment to free trade internationally and to a market system at home could be seriously eroded.

The emotionalism on this issue reflects deep-rooted U.S. insecurities-indeed, one could say paranoia. When paranoids are told there is no evidence that they are being victimized, they simply take it as proof that their attackers are extremely clever. The same is true for much of the response to discussions about the generally weak evidence that Japanese targeting has had a major role in Japanese industrial success.

I believe the United States should, in general, tolerate foreigngovernment interventions under most circumstances. But I am not totally convinced by Krugman's argument that these practices do no damage to the United States and thus disagree with his conclusion that the United States should ignore all targeting practices. In this comment, therefore, let me describe his argument, indicate where I differ, and then briefly discuss appropriate U.S. policies.

Krugman suggests that foreign practices would not be a problem if the U.S. economy really fitted the neoclassical competitive paradigm. 
Because the economy actually deviates significantly from this paradigm, however, foreign targeting may make matters worse. He distinguishes four major sources of market failure: (1) unemployment, (2) distortions in wages, (3) imperfect competition, and (4) externalities. After describing foreign targeting practices in several industries, he considers how they interact with market failures. In the case of each failure he suggests targeting abroad is likely to have done little damage: (1) Unemployment is not an important problem because employment due to manufactured goods trade in the United States actually increased during the 1970s. (2) Krugman found the automobile industry to be the only major sector with high wages and poor competitive performance, but targeting is not a major factor in its competitive problems. (3) Foreign firms have not earned the supernormal profits they might have been expected to earn if their governments were behaving in a successful strategic manner. (4) Externalities in the semiconductor industries will not be confined to Japanese firms, and the kind of dynamic economies of scale that occur in that industry are not likely to induce market failure. Krugman concludes therefore that actual targeting policies followed by U.S. competitors have caused no damage.

First, I question the notion that a competitive economy would have nothing to worry about from foreign targeting. The crucial distinction here is between targeting on U.S. exportables versus targeting on U.S. imports. In a competitive and frictionless economy, foreign promotion of goods imported by the United States hurts U.S. producers but provides consumers with an even greater gain. Foreign promotion of U.S. exportables, however, worsens U.S. terms of trade with no offsetting gain. Krugman indicates that in the past there have not been substantial declines in the U.S. terms of trade. There is a problem with this use of ex post evidence, because it deals with what actually happened instead of what might have happened had there been no targeting. Nonetheless, I agree here with his conclusion: so far, the dominant thrust of foreign targeting has been directed toward products in which the United States is a net importer, and therefore it has probably raised U.S. welfare by improving U.S. terms of trade. But the current concern is new and unfortunately is not discussed in sufficient detail in this paper: as the Japanese and others move up the technological spectrum in the industries they choose to target, they will increasingly move in on U.S. exportables and hence, in principle, may do the United States much more damage. 
Krugman notes that in the 1970s trade did not induce a decline in U.S. manufacturing employment; he therefore dismisses the unemployment argument. But in looking at the long run he overlooks one form of targeting on U.S. imports about which the United States should not be indifferent, which is targeting that in the short run leads to the exporting of unemployment. When there is great excess capacity worldwide in an industry such as steel during periods of generally high unemployment, subsidizing steel exports is a beggar-thy-neighbor policy. While the United States gets the benefits from cheap steel imports, it also pays the costs of unemployment and trade adjustment assistance not reflected in private calculations. The current laws against dumping deal adequately with these cases. They require the demonstration of injury and then permit countervailing duties. We do not need new policies here. Nonetheless, this is a form of targeting the United States does not and should not accept passively.

Krugman turns to the case in which targeting may make the United States worse off because of a flaw in its own labor market: wage premiums that exist in some industries because of institutional factors. Whether targeting does make the United States worse off in this case depends crucially on whether the wage premium is unaffected by the foreign competition. To the degree the premium is narrowed, the nation gets two types of benefits, one from the reduction of monopoly and the other the usual gains from trade. As Krugman notes, the best solution for the country has nothing to do with targeting; it is to get rid of the distortion introduced by the wage premium. This is an example having little to do with targeting per se and in my judgment does not deserve the space devoted to it in this paper.

Krugman rejects suggestions that foreign targeting has worked in a strategic setting, because he asserts foreign firms have not been very profitable. He offers some citations but presents no systematic analysis of profit behavior that is adjusted for the business cycle and so forth. Indeed, I think this reflects a more general problem with the paper. It claims to be dealing with all types of targeting and has defined these practices very broadly, yet the empirical evidence is highly selective. Either we are looking at a comprehensive survey or at a few examples, but the scope of the study has to be made more precise. By the way, on the question of profits, Krugman does find that the Airbus is being subsidized. Presumably Boeing is being hurt. How does this finding 
square with the conclusions of the study that there is no evidence of damage?

Since I accept that, at least in principle, foreign targeting may make the United States worse off, I want to outline briefly what its policy response should be. Before doing that, however, let me stress one point. It must be recognized that international trade can never be fair in the same way that domestic trade is fair. Efforts to make trade fair in the sense of getting everyone to play by U.S. rules are likely to be counterproductive. Fair competition between domestic firms is possible because they all operate in the same environment, and therefore their fate is determined by their own actions rather than those of their government. Yet international trade occurs precisely because firms have access to different environments. Environments differ because of basic endowments such as natural resources and climate. But they also differ because of social conditions such as political systems, laws, and degree of government support. Too often we hear it suggested that because government actions affect comparative advantage-indeed because governments can create comparative advantage-trade theory is irrelevant to the real world. Yet, taking intervention as given, the principle of comparative advantage and arguments about the potential gains from trade remain perfectly valid. In a pluralistic world, nations need to accept the existence of different economic systems; they cannot confine trade only to systems similar to their own. When the United States trades with the Soviet Union, to take the most extreme example, what does fair trade mean? Yet they trade with each other because both nations gain.

Having said this, what should U.S. policies be? The general rule should be to deal with targeting only where (1) it clearly damages U.S. welfare and (2) U.S. government action can make the United States better off.

When it comes to competition in the domestic U.S. market, existing trade laws lead to a reasonable policy. The real issue is how to ensure that the U.S. government follows its own procedures and does not circumvent them with so-called voluntary restraints, which violate the spirit of the laws. We should, as these laws allow, provide temporary protection, ideally in the form of tariffs, to firms experiencing substantial dislocation because of trade. This seems to be an imperfect but reasonable compromise between the costs of dislocation to producers and the benefits to consumers. 
It is much tougher to deal with competition abroad. The United States may have some scope to behave strategically so as to persuade others to reduce or eliminate export subsidies by matching them. But this approach should be tried only if political judgment indicates it can be effective in leading others to reduce and ultimately eliminate these practices. Otherwise, taking foreign subsidies as given and blindly matching them will simply make us worse off.

The United States is also aided by foreign antidumping laws, which inhibit "unfair" competition against U.S. exports in third markets. Indeed, I view U.S. antidumping laws, which hurt U.S. consumers, as a contribution to an international order rather than a purely domestic action. Lastly the United States must maintain pressures to open foreign markets both to U.S. exporters and to U.S. direct investors abroad. In particular, it should insist upon national treatment for U.S. multinationals abroad. As foreign productive capabilities increase, multinationals will increasingly become two-way conduits of knowledge. Learning economies are crucial for high-tech firms, and since the United States opens its markets to others, its firms should enjoy similar access to developed countries abroad. U.S. firms in Japan, for example, should be allowed to participate in Japanese national industrial programs. Let me end with a well-known caution: just because you are paranoid, it doesn't mean they are not out to get you.

\section{General Discussion}

Wing Woo questioned whether the absence of excess returns in a foreign industry indicated that industrial targeting in support of that industry had been unimportant or unsuccessful. The possibility that the monopoly rent of such an industry had been shared with, or even captured by, foreign labor unions made this criterion unsatisfactory, for in such cases the monopoly rent being extracted would not appear as excessive profits. Thomas Juster added that, even where targeting had been successful, foreign firms might bide their time in collecting such monopoly rents. After penetration of the targeted market, such firms may maintain the competitive price for a substantial period in order to build brand loyalty before appropriating the monopoly rent. Thus the current rate of return is, at best, a measure of the degree of monopoly power currently being exercised and not a good indicator of the success 
of foreign industrial policies. Juster thought that the behavior of Japanese firms in the automobile industry was characterized by such a pricing strategy.

Peter Clark observed that the case for protecting an industry in which substantial union wage premiums exist neglects a potentially important dynamic element in the wage determination process. Rather than the case Krugman emphasized, in which a portion of the domestic union's monopoly rent is transferred to the foreign firm, Clark emphasized that competition from foreign firms would diminish the wage distortion as domestic firms toughened their position in wage negotiations and unions' trade-off between wages and employment deteriorated. In the case of the automobile industry, it may not be politically feasible either to confront the union directly or to provide a wage subsidy in order to eliminate the wage distortion; but lifting the voluntary quota would set in motion market forces that would reduce the domestic wage distortion. Krugman acknowledged this possibility but questioned its political reality. He noted that the wage in autos, which is currently 1.7 times the average wage, would have to be reduced to 1.2 times the average wage to make the Japanese threat to the industry minimal.

Participants questioned, on several grounds, the basis for fearing and reacting to foreign targeting. Carlos Diaz-Alejandro reasoned that only a foreign monopoly, however created, can compete with a domestic monopoly like Boeing. It is inappropriate to come to the aid of a monopolist when its traditional turf is being invaded. James Duesenberry saw import competition, from whatever source, as vital in the Schumpeterian process of creative destruction. The survival of only the most efficient and innovative domestic firms contributes to continued improvements in the standard of living. He also observed that import competition disciplines output pricing, which in turn restrains wagepush inflation. Benjamin Friedman felt that the historical record made one optimistic about America's ability to compete internationally. He recalled that Japan is only the latest of many foreign "threats." Not long ago the popular press was predicting the demise of American industries in the face of the superefficient German and Swiss manufacturers. Today, however, even the chairman of the President's Commission on International Competitiveness publicly refers to the Europeans in this context as "a basket case."

Charles Schultze warned that any government-sponsored response 
to perceived foreign industrial policies would tend to degenerate into a pork-barrel response to imagined foreign industrial policies. He saw the rigidity observed in the European economies as partly traceable to preserve-the-loser policies that developed from political pressures there. Krugman supported Schultze's concern about how an industrial policy would evolve. He cited the work of Grossman and Dixit showing that the optimal strategic trade policy requires detailed knowledge of the production process and the nature of the competition for each industry. In practice, with such intimate knowledge unavailable, political pressures would dominate even a well-intentioned and well-designed government industrial policy. 